\title{
COOPER-HEWITT MUSEUM
}

\section{SILVER IN THE COLLECTION}


WASHES

encoshas

$\bar{m}$

WASHIS

m

o
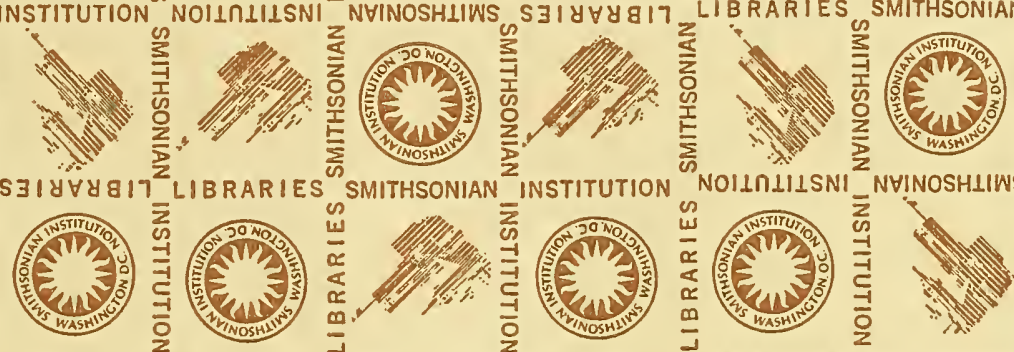

w

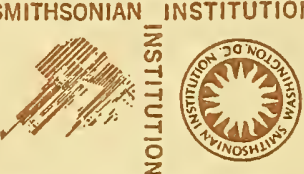

\section{.}
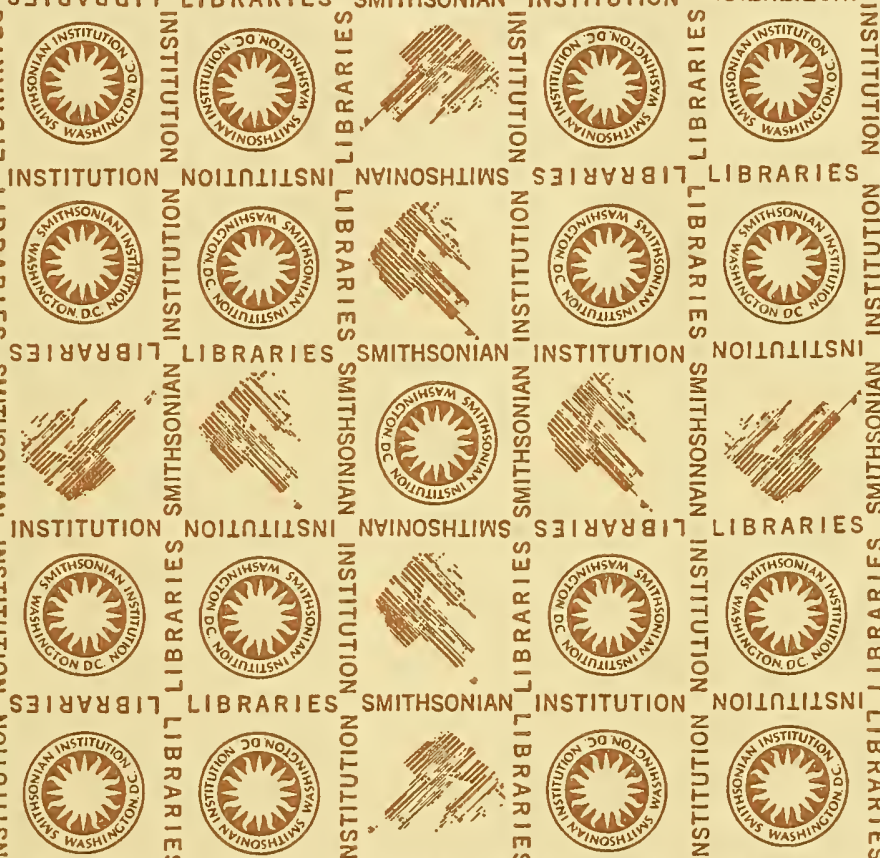

SMITHSONIAN
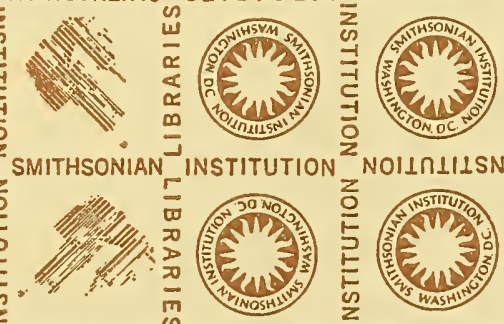

NOIINLIISN
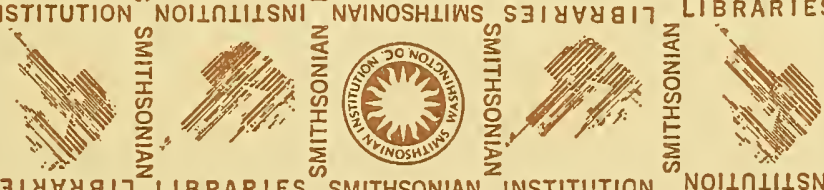

곤
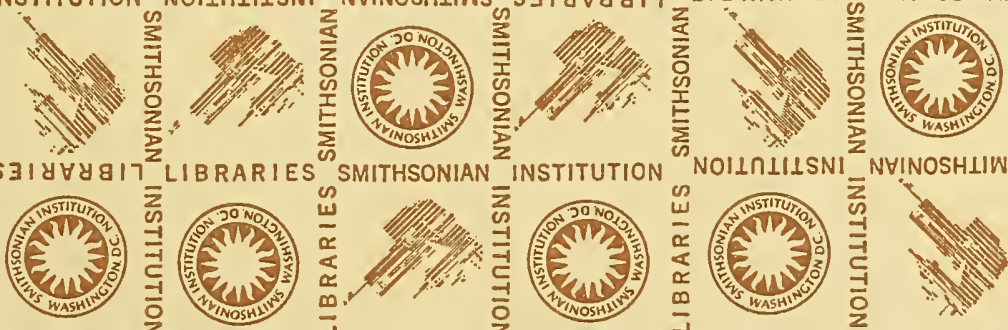

NYINOSHLIWS

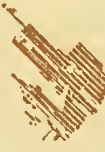







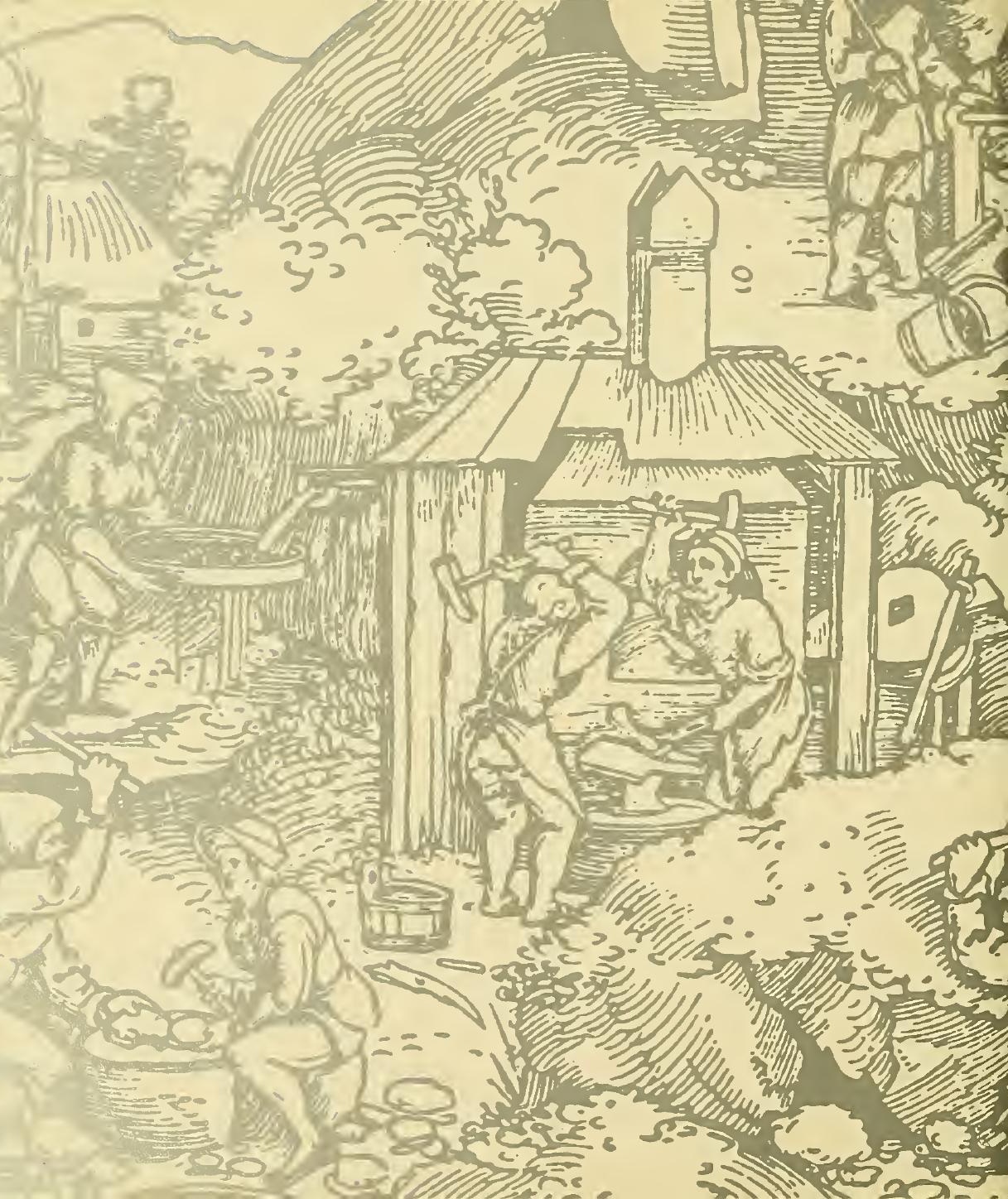




\section{Silver}

Nk in the Collection of the Cooper-Hewitt Museum,

\section{SMTHEORAX \\ APR 41983 \\ Lieraries}

The Smithsonian

Institution's National

Museum of Design 
front coter:

William Cripps (active from about 1743 ,

died about 1767)

London, England

Tea caddy (one of a pair), 1752-1753

Silver

Gift of the Trustees of the Estate of

James Hazen Hyde

1960-1-1

inside front and back covers:

from Hans Sebald Beham (1500-1550)

"The Saxon Mine" 1528

Collection Cooper-Hewitt Picture Library

Photographs by Alan Fairley

Design by Heidi Humphrey

(c) 1980 by The Smithsonian Institution

All rights reserved

Library of Congress Catalog No. 80-69558 


\section{Foreword}

Designers and craftsmen in the precious metals - gold, silver, and platinum - have traditionally held a distinguished place in the history of design and decorative arts. In contrast to woodworkers, ceramists, or glassblowers, these artisans work with materials that are inherently valuable, even in their raw and unfinished state. This has meant that decorative and functional objects made of silver and gold such as domestic tablewares, ecclesiastical and royal appurtenances, and jewelry, have been treasured and preserved not only because of their design or their symbolic value, but also because of the basic worth of the metal. The precious metals are among the most permanent and stable materials that have been used in the making of beautiful and useful objects, and yet among the most susceptible to destruction through melting or refashioning. Treasures that have remained in an original form from the past are few in comparison to the number that once existed.

A museum collection preserves rare and unique documents of decorative arts history for posterity against the tides of economic necessity. The Cooper-Hewitt collection of silver and other precious metals has grown steadily since the founding of the Museum.
The collection is comprised of objects of primarily European origin and illustrates many major styles and forms used by silversmiths and goldsmiths from the 17 th century to the present.

This publication provides an introduction to the collection of silver in the CooperHewitt Museum. It was made possible through the kindness and generosity of the Sterling Silversmiths Guild of America whose members are The Gorham Company, International Silver Company, Samuel Kirk \& Son, Inc., Lunt Silversmiths, Oneida Silversmiths, Reed \& Barton, The Stieff Company, Towle Silversmiths, and Wallace Silversmiths.

\section{Lisa Taylor}

Director 


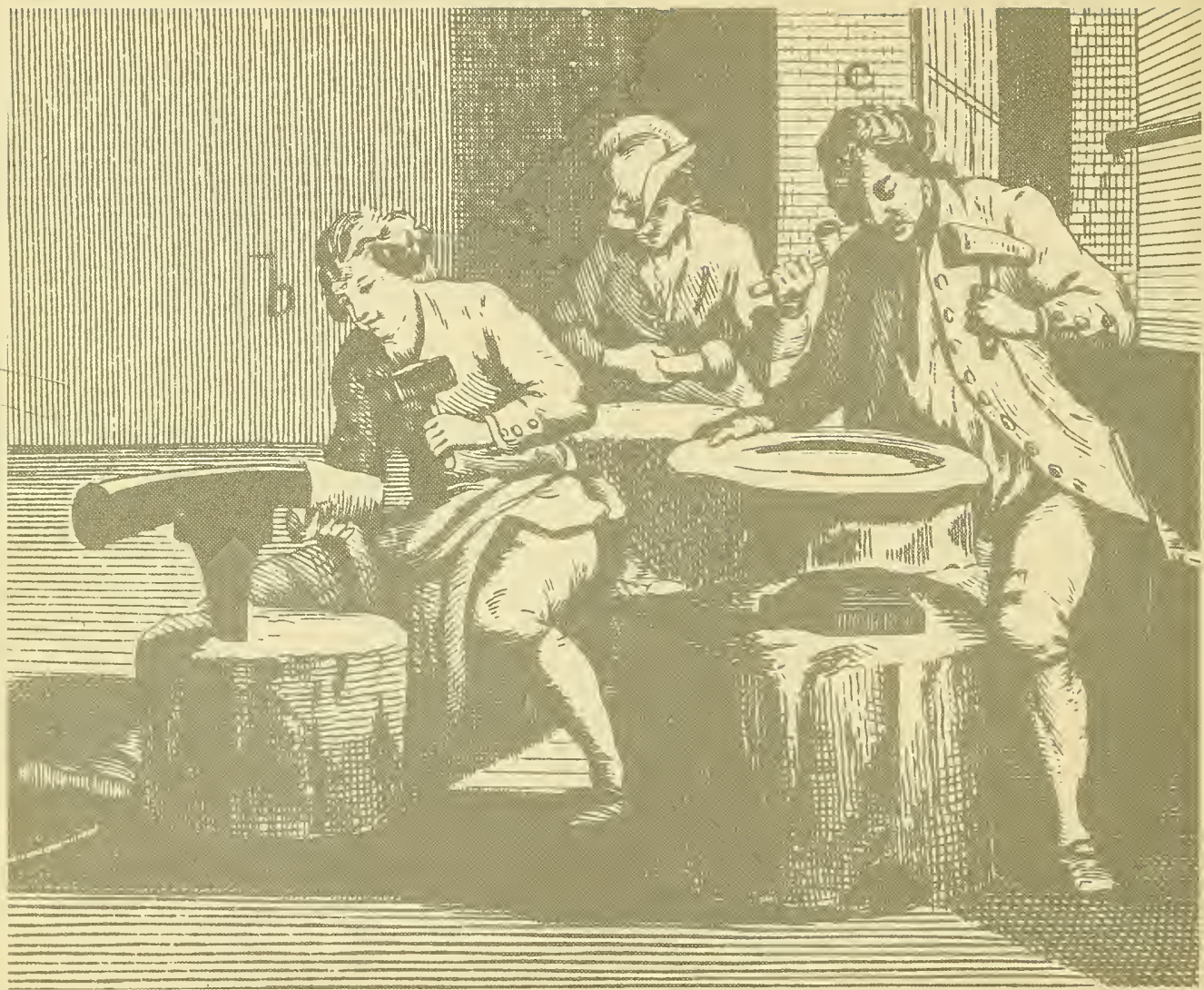

"Silver Workshop in the $18 \mathrm{rh}$ Century"

from Denis Dideror Encyclopédie

Paris, 1771

Collection Cooper-Hewitt Picture Library 
The recognition and use of metals is an ancient and distinguished fact in human history. Nearly every stage in the progressive development of metallurgical knowledge has been documented by objects that reflect both the intellectual comprehension of the nature of materials and the human need to reshape raw materials into forms that are functional and pleasing to the eye. Early man first recognized the utility of those metals that were readily available or accessible in a native state; copper and gold, for instance, often appeared as nuggets or solid masses that could be collected or extracted easily ftom the earth. Native finds of such metals could be shaped by simple hammering with virtually no intermediary steps. Understandably, these two metals were the first to be shaped by man to fulfill specific purposes. From the outset, metals were treasured rarities and treated with concomitant respect and admiration. At the preliminary stages of metallurgical science it was recognized that metals were more malleable than stone, more durable than wood, and could be treated to produce a lustrous or reflective surface. Metals could also be subjected to heat to transform the solids into fiery liquids that could be poured into predetermined shapes. All later developments in the history of metalworking are based on these simple but astounding qualities of the materials.

A major advance in the understanding of the potential of metal-either precious or base - was the discovery that metals are not always found in a pure state, but that they may exist "trapped" within a composite mixture of elements that have different melting temperatures. By heating such composite "ores," the various constituent metals are released. Mining of ores for purification by heat refining became a major industry, and the entire process rapidly took on a scientific character. Although silver may be found in a native state, most often it is contained in tich lead ores; the growth of the silver industry was dependent upon a sophisticated technology that permitted the precious substance to be extracted from the ore.

Silver was appreciated as a precious metal somewhat later than gold, but its use can be traced to the prehistoric era. Silver was prized by many ancient civilizations and, like gold, symbolic and magical qualities were credited to it. In the ancient Near East, for example, gold and silver were identified cosmically with the worship of the sun and moon. Silver and gold continue to enjoy special distinctions within the family of metals. Until the nineteenth century they were, in fact, the only metals classified as "precious." Today, only platinum and platinum-related metals share this position of eminence. The preciousness of gold and silver is the result of several inherent properties, as well as impressive acquired significance. Of basic importance is the fact that gold and silver are the most malleable of metals. This means that they are easily shaped and stretched by the application of pressure. Gold is the more malleable of the two, and is capable of being flattened to a semitransparent thinness without breaking or cracking.

The sisterhood of the two metals is also revealed by their shared property of ductility, a characteristic that was early recognized and appreciated by metalworkers. Ductility of a metal is its ability to be drawn or pulled into the form of a wire. One ounce of gold may be stretched into wire several miles in length without breaking. Again, silver is second only to gold in this property.

Both silver and gold are highly lustrous, a third characteristic that man has found of primary interest for thousands of years. 
Both metals can be polished to mirror-like brilliance and do not become dull with use or handling. Although silver may tarnish when in contact with polluted air or sulphurous substances, it is nearly as noncorrodible and as non-tarnishing as gold when free from such agents. Both metals, and gold in particular, came to symbolize permanence, stability, and purity. These attributes have made the two metals important standards in most world religions, social systems, and economic structures.

Gold and silver are also among the rarest of metals. This quality alone has given the two metals a desirability far above all other base metals. Silver and gold have never lost this position of pre-eminence, as our monetaty system and luxury trades indicate. From the earliest historic periods to the present day, auspicious occasions, special events, and ecclesiastical and domestic rituals have been celebrated and commemorated with the use of the $t$ wo metals.

Since ctaftsmen began working silver and gold, the forms of the objects made, the functions that they serve, and the decoration that is a part of them have changed dramatically over time. It is often possible to recognize the age and origin of an object of silver or gold by its physical appearance alone. Each culture or society, each generation, and each craftsman endows an object with distinct characteristics that indicate its position in the history of design. However, the ways in which craftsmen have manipulated silver and gold from the initial processes to the final completion of an object have changed astonishingly little over the millenia. During the late 18 th and Igth centuries, mechanized processes began to replace many of the activities formerly accomplished by the hand; however, a modern handwrought object in silver or gold still requires the knowledge of techniques that have been a part of the vocabulary of metalsmiths for at least 4000 years. A craftsman learns the potentials and limitations of materials through a continuous process of experimentation and repetition. An understanding of the manner in which materials have been shaped by the hand and mind of the craftsman brings the process of design into clearer focus. Silver and gold literally and figuratively reflect the society that uses precious metals; through the examination of some of the multiple aspects of history that surround an object, an insight into the process of design is permitted. The Cooper-Hewitt collection is comprised of silver representing diverse cultures, periods, styles and designs, with a majority of works dating from the post-Renaissance period to the present. Within this time framework can be seen facets of the aesthetic, social, political, and economic setting that give texture to the genealogy of the decorative arts.

By the $17^{\text {th }}$ century, nearly every European nation had a firmly established tradition of design in the precious metals. Silver and gold were central to the economies of any geographic entity, and the craftsman who worked in the field was an essential contributor to the survival of the society. Not only were these craftsmen the primary agents in the circulation of precious metals in the form of objects, but the integrity of their work, the purity of their materials, and the conscientious control of standards that they were required to exercise assured their status in society. Their materials were not only used for the luxury trade but were directly related to the currency of their native land. It was accepted that an object of wrought silver or gold could be converted at any time to usable currency or bullion by its owner, and any variance in the standard of purity between the object and the currency could spell disaster. The silversmiths and goldsmiths were responsible for maintaining the quality of such standards, and any deception in their practices could have devastating economic consequences. As a matter of self-protection, and often at the behest of civil authorities, precious-metal workers joined together to form guilds of goldsmiths. In the guild structure, no distinction was made between workers in silver and gold, and the term "goldsmith" always covered work in either or both metals.

Guilds not only enforced among their own members an adherence to accepted standards of alloying and fashioning of the metals, but also provided a training resource for the education of future craftsmen. Demanding and closely supervised apprenticeship systems were evolved in which the candidate for guild membership had to prove his knowledge of all aspects of the art and craft by training with a certified guild master, and meeting all requirements of the guild authorities.

Certain centers of silversmithing had developed particularly strong and influential guilds and were known for the quality of their workmanship and designs. Among the leading centers in Europe during the 16 th and ifth centuries was the renowned city of Augsburg, which boasted a substantial number of quality workshops and exported silver and gold to many other parts of Europe. In the Cooper-Hewitt collection is a superb ornamental charger (Figures $\mathrm{ra}-\mathrm{f}$ ) by the Augsburg master Adolf Gaap, who was active in that city from about 1664 onward and died in 1695 . Of impressive size, this charger embodies several general concepts of design current in 17 th-century Germany. An important aspect of the charger is its size, indicating a public display of wealth. The charger was probably never intended for practical use since the highly embossed decoration mitigates its function as a serving dish; its real use was to serve as an elegant reminder of 
4.

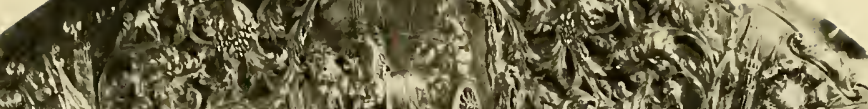

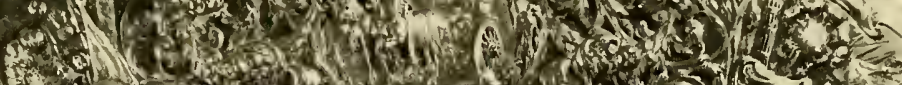
2
5

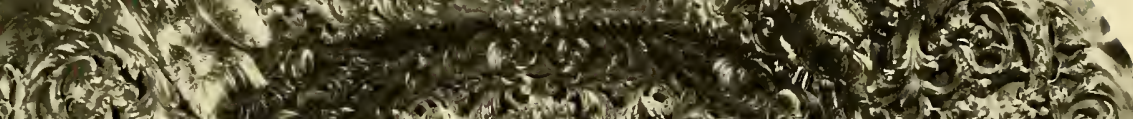

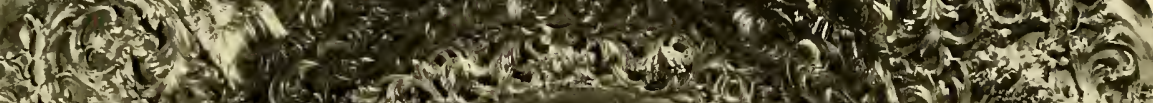

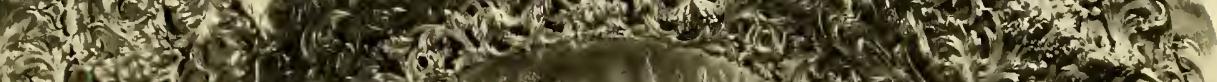

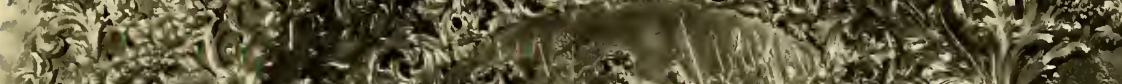

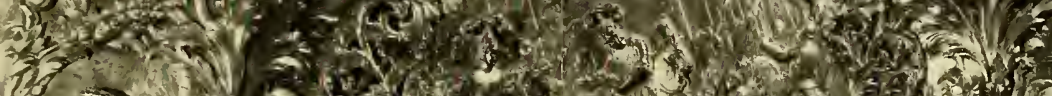

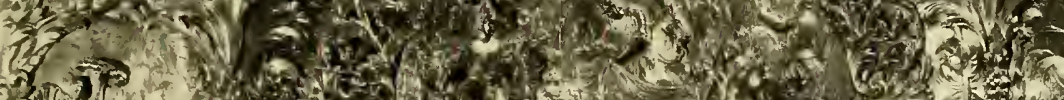

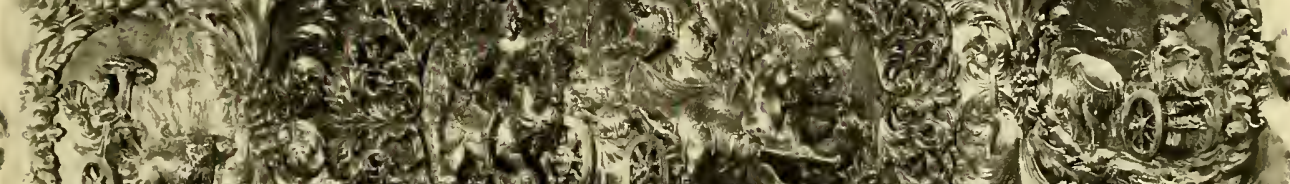

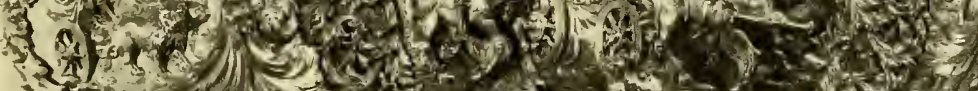

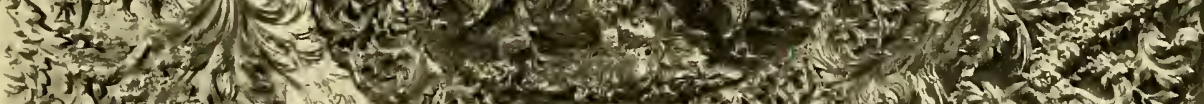

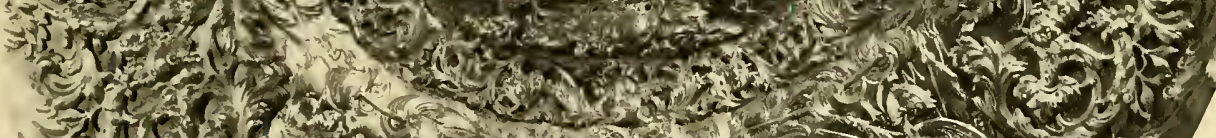

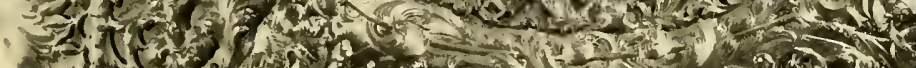

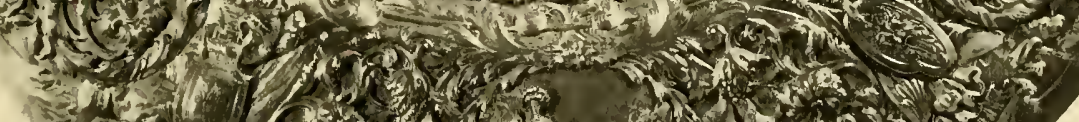

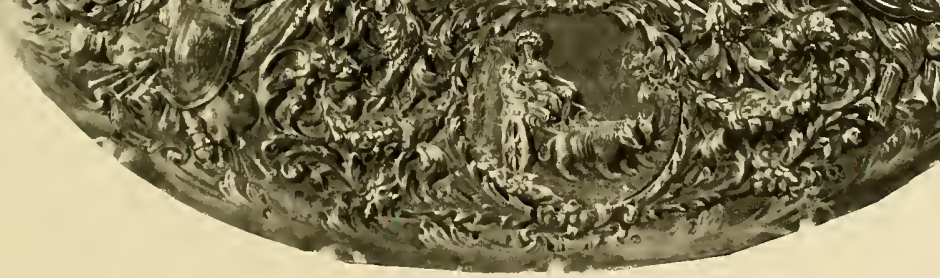


b. Detail of the central relief

"Alexander mourning the death of Darius'

c. Detail: Figure of Asia

d. Detail: Figure of Europe

c. Detail: Figure of Africa

f. Detail: Figure of America

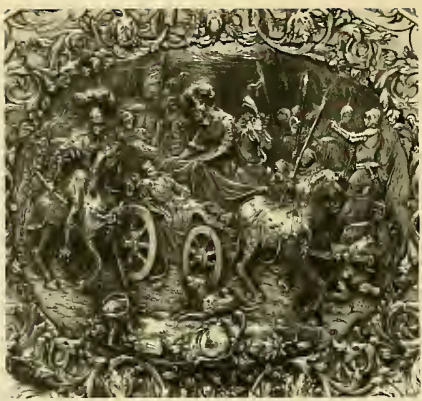

,b.

panels that personify the four continents of the world; Asia (Figure Ic) in a chariot drawn by a pair of massive elephants; Europe (Figure Id) accorded the honor of position at the top of the charger; Africa (Figure ie) with a peacock feather parasol and paired lions; and America (Figure if), whose chariot is drawn imptobably by two outsized armadillos. These panels are surrounded by a writhing network of scrolled foliage, fruit clusters, and trophies, all enriched by a layer of gold to assure the awesome splendor of the design.

Not all 17 th-century silver was conceived or executed on such a grand and imposing scale, nor did all have such a purely ornamental function. Drinking vessels, such as beakers and bowls, also constituted a large portion of the output of silversmiths' workshops. A beaker made in Danzig (Figure 2) is typical of a traditional shape. Made in the second half of the century, this beaker reflects a conservative form that remained popular for centuries. This example, however, incorporates timely and fashionable decoration on its surface. The world of observable nature is depicted on the beaker in a parrot tulip, lily, and narcissus bloom. These

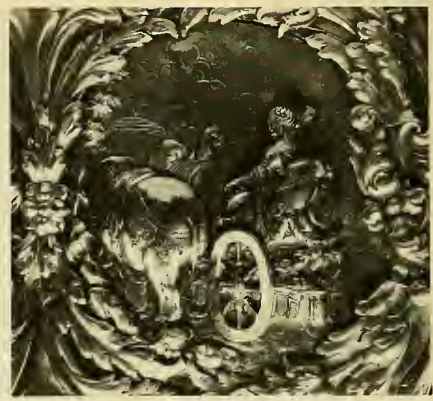

IC.

exotic bulbs and plants were prized by horticulturists and suppliers alike. The motifs have been applied to the surface of the beaker with the delicate and careful use of a hammer and punch, a technique known to silversmiths as "chasing." A more abstract sense of natural form is incorporated at the lip and base of the beaker, suggestive of marine life, with convoluted ear-like folds depicted as a continuous border. A restrained luxury of decoration is indicated by the gilt interior, foot ring, and floral motifs. Until quite recently the traditional manner of gilding silver was to amalgamate gold with mercury to form a thick paste. The paste was applied to the silver surface; when subjected to heat the mercury burned off in a toxic vapor, leaving behind a residue of gold. Needless to say, mercury gilding was exceedingly hazardous to the health of the craftsmen, for whose services a substantial fee was paid, but whose careers were generally short. Since the layer of gold on mercury-gilded pieces was thin, it nearly always suffered through use, and only traces of the gold remain on portions of this beaker.

\begin{abstract}
graphic exploration. Around the edge of the charger are four additional inset

battle chariot. The source for this composition can be traced to contemporary scholars and collectors. Not only were the patrons of 17 th-century silversmiths still enjoying the world of classical legend, but also the contemporary field of geo-
\end{abstract}




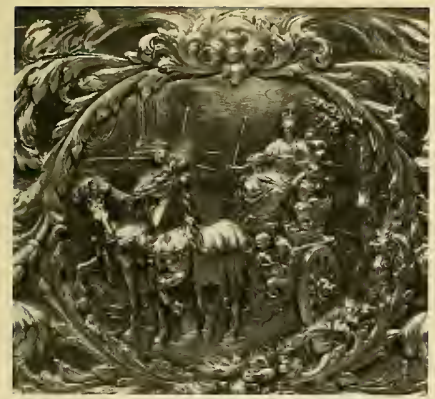

id.

Guild traditions in Europe can be traced to the medieval period, and the guild of goldsmiths was particularly well organized in London. By the late 17 th and early 18 th centuries, English silversmiths had proven their united effort to maintain the quality of their art. The Worshipful Company of Goldsmiths, formally chartered by Edward III in 1327 (although a guild was known to exist as early as i180), required that all of the legitimate members of the guild enter, at the guild hall, a record of their personal mark used on silver. In addition to this protective stamp, which clearly indicated the workshop from which a piece of silver came, additional systems of counter checking were instituted over the years that virtually assured the quality and integrity of English work. Although most countries in Europe developed their own system of controlling the purity and quality of silver, a typical set of late 18 th-century English marks (Figure ${ }_{3}$ ) reveals quite specific information. Since each piece of wrought silver was required to pass an assay master's test for the purity of the alloy used in all parts of the object, a series of marks placed on the object at the guild hall (hence, "hallmarks") specifies where and when the assay was made, assures the buyer that the alloy was up to standard, and that any

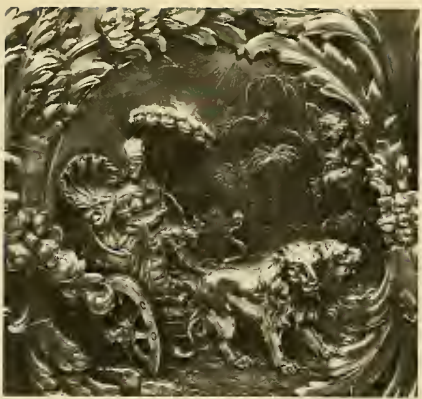

Ie.

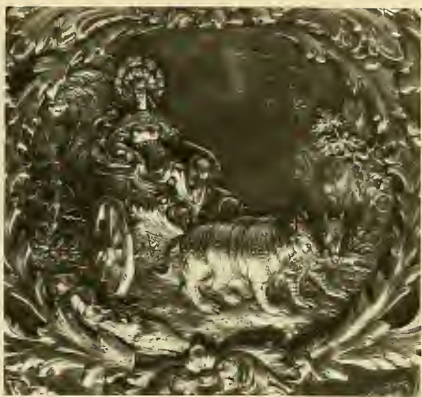

If.

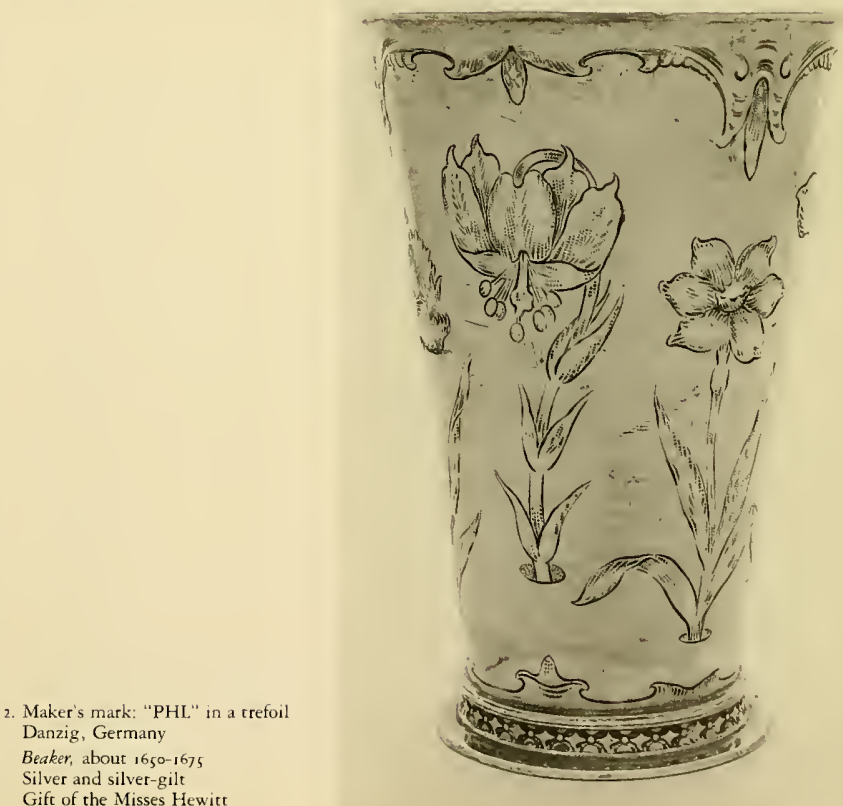

Gift of the Misses Hewitt $1931-48-95$ 


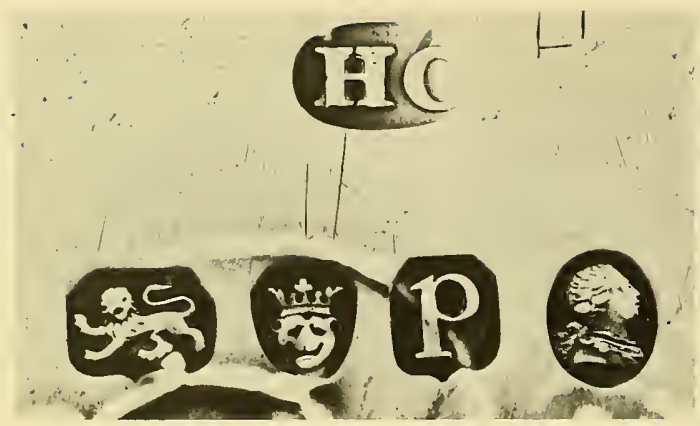

3. Set of ballmarks:

Henry Chawner; Sterling Silver; London, 1790-1791; duty mark necessary taxes or duties had been paid on the silver. In the example illustrated, the initials " $\mathrm{HC}$ " in an oval are those entered in the ledgers of Goldsmiths' Hall by Henry Chawner on November 11,1786 . The figure of a striding lion indicates that the silver used in the fabrication of the object was at least as pure as the sterling standard; in other words, each 1000 parts of metal is composed of no less than 925 parts of pure silver. The remaining 75 parts constitute the allowable alloy. In most cases, the alloy metal used for silver was copper. This metal combines freely with pure silver, which alone is too soft for use and makes it stronger. The crowned lion's head mark attesrs to the fact that the silver was assayed in London. The letter " $\mathrm{P}$ " in a shaped stamp indicates that the assay was made between 1790 and 1791 , the date letter being changed annually. The portrait head mark, used from 1784 until 1890 and since then occasionally for commemorative purposes, depicts the reigning sovereign and verified that any tax or duty on the silver had been paid. The English hallmarking system has had various deviations from the system described, but the assurance given by such marks is clear: a dishonest silversmith could be easily traced by his personal mark on the piece, and suspect assay masters or offices could be precisely described, including the city and year when the assay was made.

By the early years of the i 8 th century, English silversmiths were enjoying a revitalized period of production. The i7thcentury Civil Wars had ended, the monarchy under Charles II had been triumphantly restored in 1660 , and a rising class of wealthy merchants provided constant encouragement to the craft with orders of substantial amounts of silver for domestic use and display. With the introduction and popularization of new delights for the palate in the form of coffee, tea, and chocolate, silversmiths found an eager market for tablewares made to facilitate and enhance the taking of enjoyment from these drinks. A tea kettle and stand by the London silversmith William Fawdery (Figure 4 ) is representative of the quality of design and conscientious execution of silver vessels during this "classic" period. The kettle is supported upon a substantial frame that contains its own spirit lamp to heat the water. The body of the pot is capacious and the facetted spout fitted with a diminutive hinged flap to prevent steam evaporation. Since silver is known to be a good conductor of heat, its use for such heating utensils was logical. However, its conductive properties also made it uncomfortable or even dangetous to handle when heated; silversmiths often incorporated nonconductive handles and finials of wood or other materials on tea and coffee vessels to prevent unexpected surprises.

The career of the silversmith who made this kettle is typical of the lives of many silversmiths active in eatly 18 th-century London. William Fawdery was apprenticed as a youth to another silversmith of distinction, Robert Cooper, in 1683. In 1694, Fawdery had completed his apprenticeship (the usual length of time was about 7 years) and was "freed" by the Worshipful Company of Goldsmiths. This meant that Fawdery was allowed to operate his own workshop, have assayed and sell his products, and take on his own apprentices. Fawdery's shop was located on "Gold" street, a part of the area in London where a majority of silversmiths set up their shops near the guild hall. Being a native silversmith, Fawdery was among the London silversmiths who objected to the large number of Huguenot goldsmiths who were moving to London to avoid religious persecution in France, and signed a petition to restrict the activities of these "foreigners." As was often the case, 


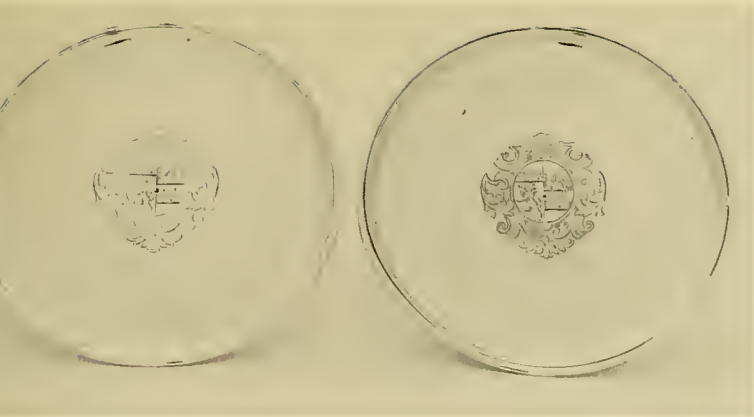

upon Fawdery's death around 1727, his widow Hester entered her own matk at Goldsmiths' Hall and carried on the family business. There is no indication, however, that Hester Fawdery was a trained silversmith in her own right.

London was not, of course, the only active center for silversmithing in the 18 th century. A vital organization of craftsmen was also flourishing in Ireland, particularly in Dublin.

A pair of early i8th-century Irish footed salvers (Figures $5 \mathrm{a}, \mathrm{b}$ ) consists of a flat dish with a molded edge supported on a hollow trumpet-shaped foot. Unimposing in design and asceric in decoration, each salver is engraved with a family coat of arms within a scroll and foliage cartouche. An inscription on the underside of each links the pair to the family of Louis Crommelin, and suggests that they may have been purchased or acquired by the family to commemorate the death of a relative.

English tradition in the design and manufacture of silver extended it self across the vast expanse of the Atlantic Ocean, where in colonial America many silvetsmiths plied their trade in the active young cities of Boston, Philadelphia, and New York.
4. William Fawdery (active from about 1694 , presumably dead 1727)

London, England

Teakettle and stand with spirit lamp, 1711-1712 Silver (Britannia standard)

Gift of Irwin Untermyer 1957-11-1
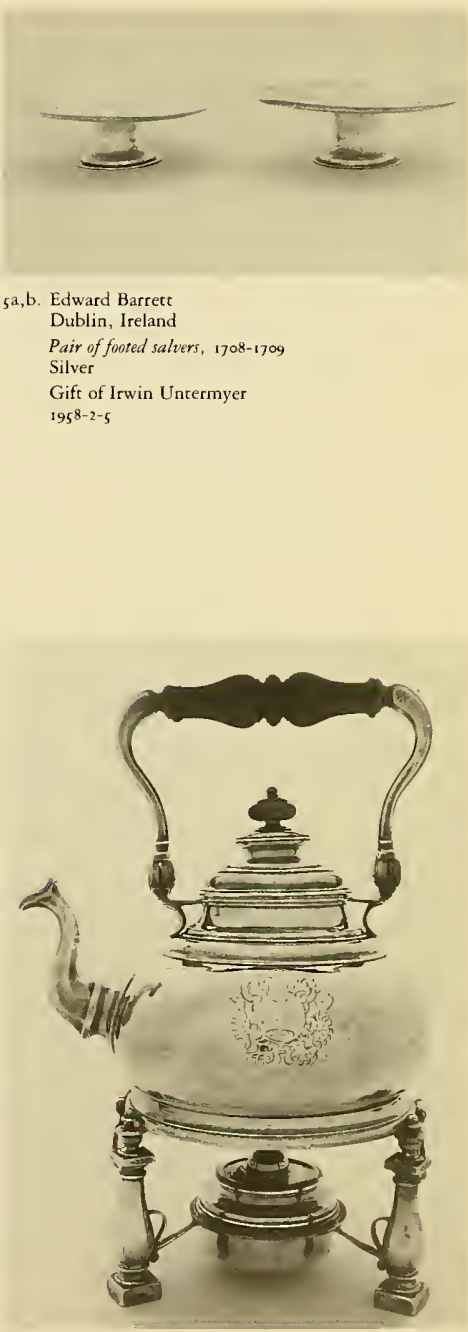


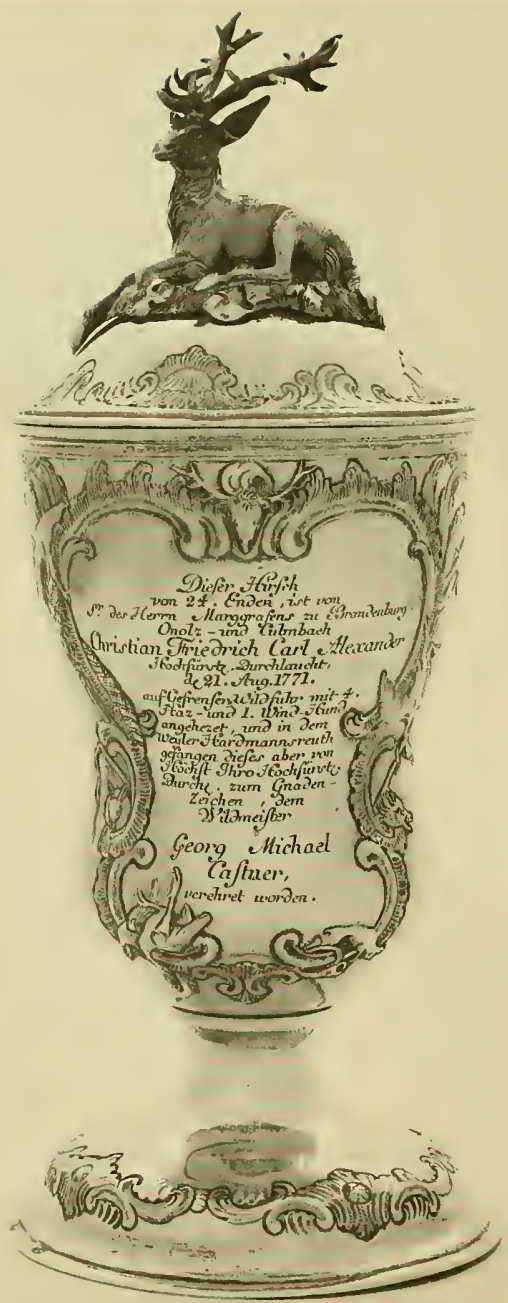

7. Abraham Drentwet (died 1785) Augsburg, Germany Tropby cup, 1773-1775 Silver

Anonymous gift 1949-131-1 
Not all early Ametican silversmiths were of English extraction or training and the Dutch and French immigrants both contributed greatly to the formation of an American style; however, the English methods of working in precious metals were cleatly evident. A simple porringet (Figure 6) in the Museum collection is the work of the Boston silversmith Jacob Hurd, whose mark is stamped on the upper surface of the pierced foliate handle. The porringer form was known in the 17 th century in America, and remained popular thtoughout the 18th. Most Ametican silversmiths made porringers in the course of their careers and the form was frequently used as a commemorative piece to celebrate marriages, often indicated by the initials of owners or couples engraved or pricked on the handle surface.

No governmental agency in the colonies enforced legal requirements regarding the alloying or assaying of silver in America during the $17^{\text {th }}$ and 18 th centuries. Since the majority of rhe founders of the tradition of silversmithing had trained within the guild and apprenticeship system of the Old World, standard practices were maintained. American silversmiths were apprenticed in a manner similar to those in

6. Jacob Hurd (1702-1758) Boston, Massachusetts Porringer, about $174^{\circ}$ Silver

Gift of Henry Chauncey 1960-36-1

Europe, and the respect for their art and craft that was thus transmitted continued to flourish in the colonies. Most notable of the survivals of tradition is the maintenance of the purity of the sterling alloy in the absence of an assaying system. Recent tests offet no evidence that early American silversmiths intentionally debased the standard of their wares.

American silversmiths worked for an audience that was certainly mote limited in numbets than in Europe and often more limited in resources to afford the luxury. Silver in America frequently assumed cetemonial status within both organizations and families. The loss of a piece of silver was clearly loss of money, but silver in recognizable form could sometimes be traced by description if lost or stolen. Colonial newspapers often contain advertisements seeking the whereabouts of a missing piece of silver, described in specific form and sometimes even with a notation regarding the maker of the piece.

While colonial Americans were nurturing a nascent tradition of silversmithing in the New World, European centers continued to produce master works in silver and gold for an affluent and status-conscious audi- ence. Silver was used for practical daily functions like dining and tea-drinking, but also for commemorative purposes of esoteric intent. A trophy cup from Augsburg in the Cooper-Hewitt collection exemplifies such a rarified use of silver as a testimonial award (Figure 7 ). The cup is intended to serve as a drinking vessel and the inscription and ornamentation clearly indicate the context of a hunt. Depicted on the covet is a cast, three-dimensional stag. The inscription below describes the participants in the hunt for a spectacular 24-point beast, the number of animals used in the hunt, the distances travelled, and the denouement of the story-because of the stag's unusual beauty it was released after captute. The pear-shaped body of the cup is embossed with connected scrolls, amidst which are depicted various prey-rabbit, boar, stag, and fowl.

It was not uncommon for pieces of silver to be carried by their owner on journeys or voyages, assuring the traveller the same luxuries on the road that he or she enjoyed at home. Numerous travelling services made of silver are known, including virtually complete sets for dining tables and boudoirs. Such services often incorporate in the design additional necessities made of 


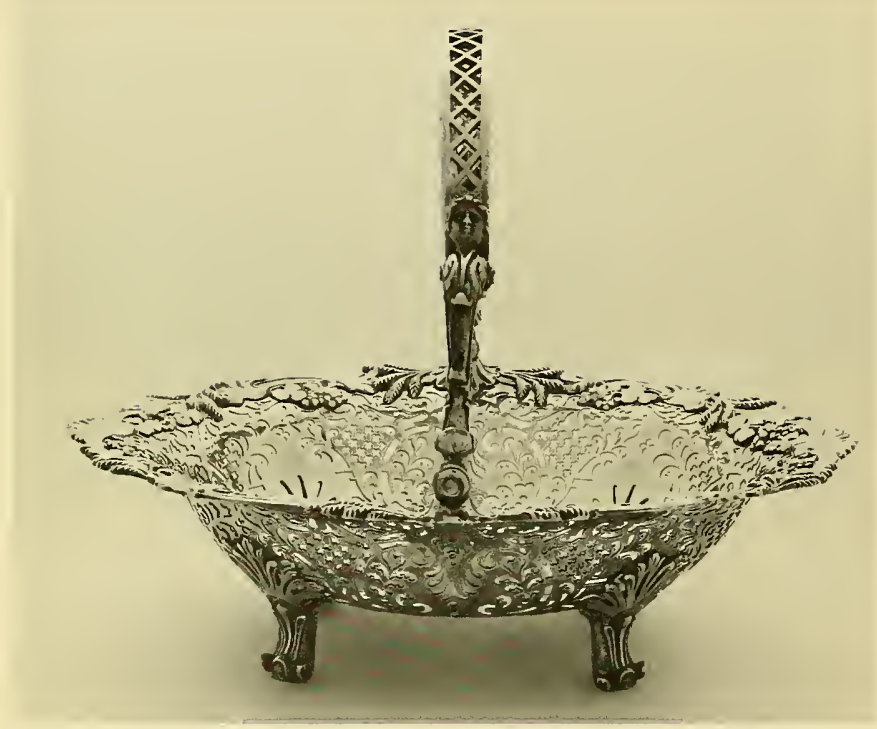

$8 a$.

porcelain or glass. Elaborate carrying cases, frequently lined with velvet or silk and bound in fine stained leather or shagreen, were constructed to hold the movable luxuries. This cup is equipped with a simulated lacquer case, decorated with gold and polychrome colors, and lined with green silk velvet.

The rococo decoration on this cup is restrained in comparison with other examples of the mid-r 8th-century style in ornamental silver. A basket made in London around 1758 (Figures $8 \mathrm{a}, \mathrm{b}$ ) confirms the popularity of the rococo taste in table acces- sories and fittings. Presumably made to hold various sweets or pastries at the dining or tea table, the basket is perched "tiptoe" upon four sctolled feet. The entire body of the basket form is pierced in a pattern of scrolls, foliage, and crosses that virtually dissolve the structure into a network of highly reflective surfaces. The body of the basket has been formed from one sheet of silver, hammered into a concave oval. With files and special piercing implements the craftsman has treated the surface of the silver in a form of negative embroidery. The strength of the thin body wall would necessarily be compromised to accommo-
$8 \mathrm{a}, \mathrm{b}$. Thomas Heming (active from 1745 , died berween 1795-1801) London, England

Cake basket, 1758-1759 Silver

Gife of Mirs. J. A. Q. Franks $1977-62-6$

date such decoration, but the problem has been resolved by soldering a continuous band of cast decoration to the edge of the basket.

Nearly every country developed a range of specialized forms in silver to be used at table. In Italy, for example, superb tea and coffee pots were made in the prevailing fashions in active silversmithing centers such as Turin, Rome, Venice, and Genoa. In the Cooper-Hewitt collection is a covered sugar bowl made by an anonymous Genoese craftsman around 1768 (Figure 9). Italian silversmiths of the mid-18th century 


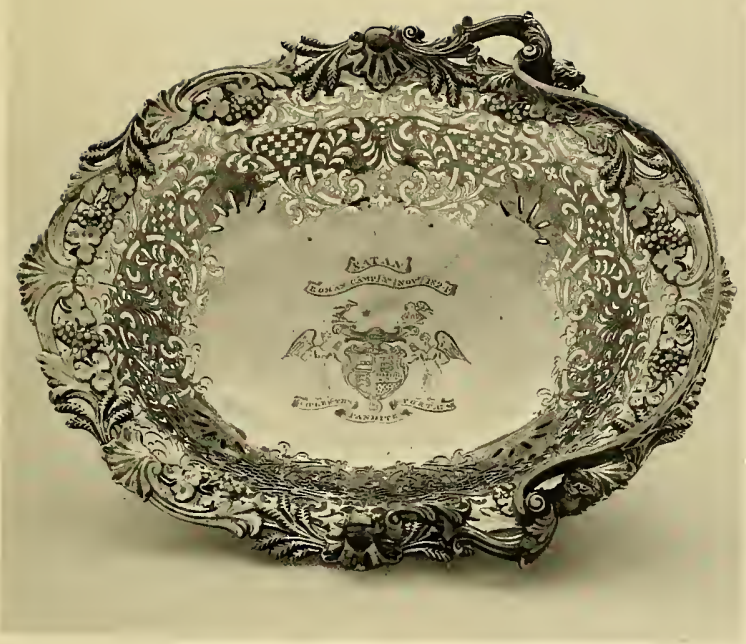

8 b.

used embossed decoration effectively to suggest weight and solidity in even diminutive objects; the overlapping leaf pattern on the base of the bowl and the husk garland that surrounds the covet are actually embossed from within to create a substantial pattern on the thin body wall. The feet and the lemon finial were cast sepatately in sand molds, a process that involved taking an impression of the desired detail from a model in a double-layered box of moist sand. When the model was removed from the sand, the mold was clamped tightly together and molten silver poured into the mold to fill the hollow patterned in-
9. Maker unknown Genoa, Italy

Sugar Bowl, about 1768 Silver

Bequest of John L. Cadwalader $1914^{-48-1}$

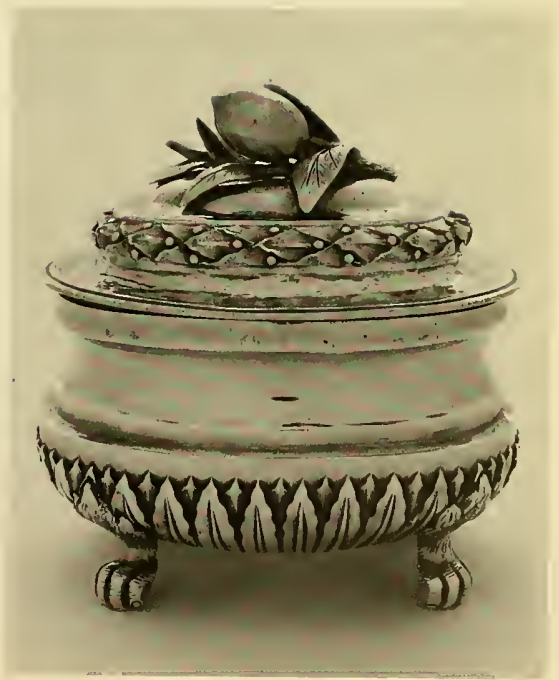




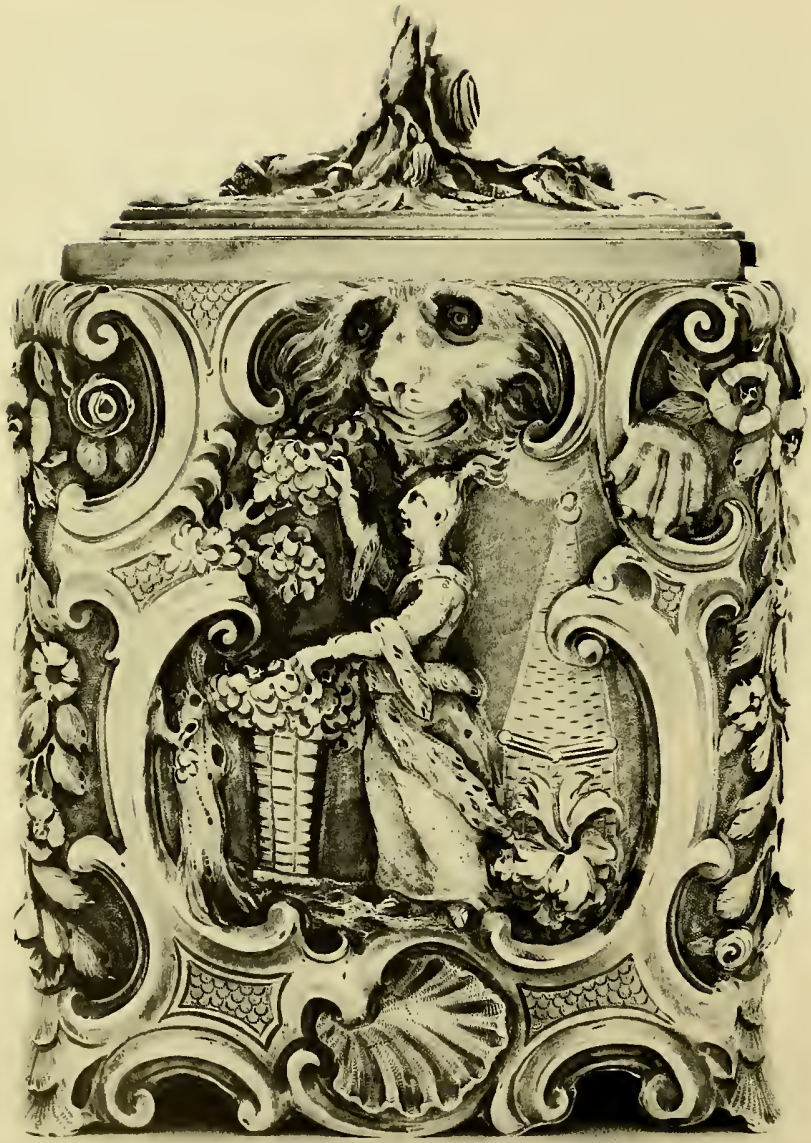

112 11a,b. William Cripps (active from about 1743, died about 1767 ) London, England

Tea caddy (one of a pair), 1752-1753 Silver

Gift of the Trustees of the Estate of James Hazen Hyde 1960-1-1

terstices. When cooled, the cast parts were removed, cleaned and finished, and finally soldered or otherwise attached to the object.

The rococo style offered silvermiths a wealth of opportunities to exploit the ornamental possibilities of techniques such as high-relief embossing and cast applied decoration. A superb example of the embosser's art can be seen in one of a pair of tea caddies in the Museum collection (Figuresi $1 \mathrm{a}-\mathrm{b}$ ). The caddies date from $175^{2-}$ 1753 and are the work of William Cripps, one of the leading London exponents of the rococo idiom. The rectangular bodies are embossed with exuberant scrolls, shells, and flowers. Within a central cartouche is depicted a fanciful Oriental figure plucking tea leaves from a bush. The entire scene is surveyed by an incongruous lion. At each side of the caddy is seen an abbreviated Eastern landscape with a central architectural structure. European taste for romantic and imaginative depictions of the mystical and legendary Orient was at a zenith around the years of mid-century. The style of decoration that the taste inspired was known as chinoiserie, a recurring theme in the West from the i7th century to the present. Appropriately, such imaginative designs were used on numerous tea-related forms, although they also appeared in much less likely contexts. Even the word "caddy"reflects an awareness of the source of tea, in that it is derived from the Malay- 
ab. Willuam Cripps Tea cadd, side view sian word kati, a weight measure used by merchants in the tea trade.

French silver of the ifth and 18 th centuries is much rarer than that of most other European countries due to the vagaries of economics and the vicissitudes of war and fashion. In 1689 Louis XIV requested that the nobility release their holdings in silver to the Royal Mint in order that France might replenish her depleted coffers and continue to engage in costly and seemingly unending wars. Undoubtediy thousands of superb objects of wrought silver were thus consigned to the melting pot, and many aristocratic households were forced to abandon the luxuries of silver for the table. Although Louis' edict had a salutary effect on the ceramics industry, in that potters necessarily stepped in with elegant replacements for tureens, ecuelles, and dishes, the damage the King's order caused to the history of French silver is incalculable. Likewise during the troubled times of the French Revolution, silver was often the victim of economic disaster due to its value as bullion. Those pieces of French manufacture that have survived to the present, day are particularly valuable documents of the supetior quality of French design and the ability of French silversmiths.

The Cooper-Hewitt collection contains a pair of French rococo candelabra by the Parisian goldsmith Claude Ballin II. The design of the lighting devices is a charming testimonial to the rococo style (Figure 12).

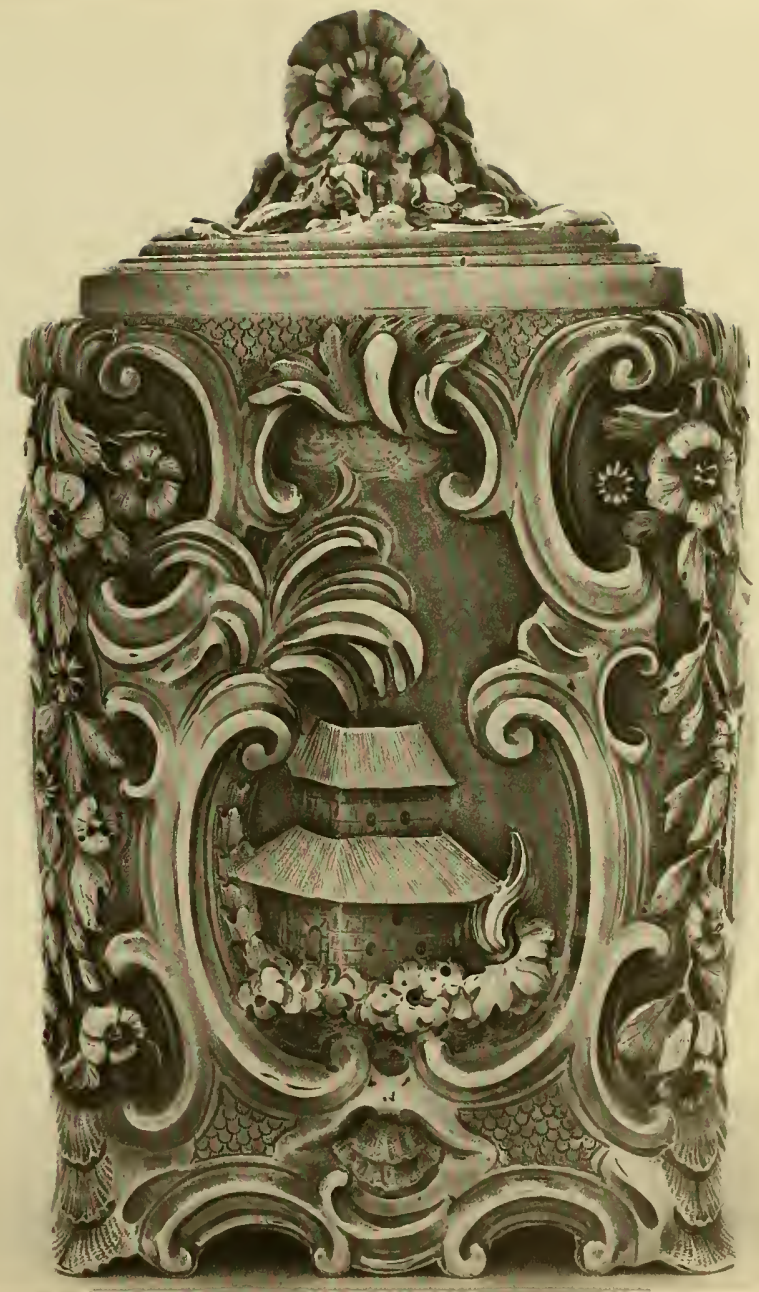




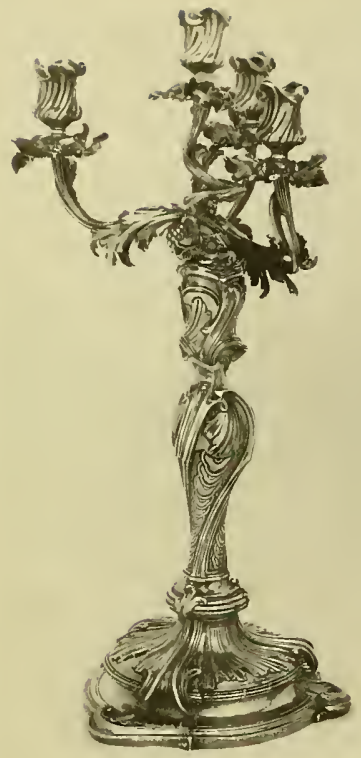

Claude Ballin's uncle was one of the many goldsmiths who worked for the Sun King, Louis XIV, and the younger silversmith was trained in this highly esteemed workshop. Claude Ballin II's own career was of some importance and included commissioned work for the Elector Maximilian Emanuel of Bavaria. The Cooper-Hewitt candelabra have cast stems and removable arms, designed in a series of writhing and interlocking scrolls and foliage. The organic, tumescent stems and the rippling branches describe the delicate and graceful choreography of the rococo. Ballin's designs for such objects were clearly related to

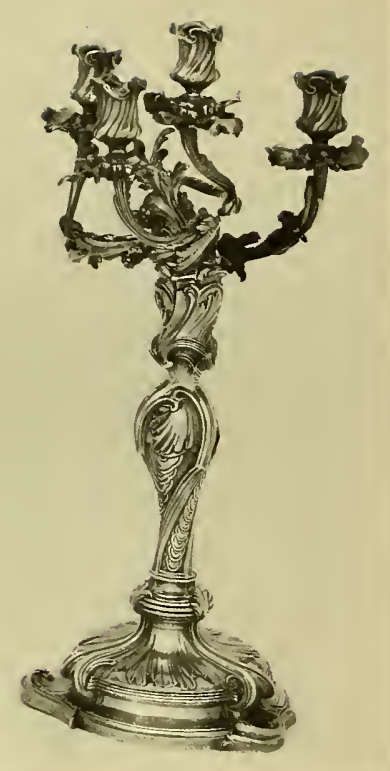

the citculated works of the great 18thcentury French ornemanistes.

Silversmiths in the 18 th century were required to produce objects for widely differing clients and an equal diversity of tastes.

Certain silversmiths specialized in particular forms, such as casters, spoons, or salvers while others produced or retailed in their shops a wide variety of objects from the most elaborate and expensive to the simplest and most ordinary. For those who succeeded with particular merit and distinction, work might even include an appointment to a member of the royal family
12. Claude Ballin II (1661-1754) Paris, France

Pair of candelabra, $1739^{-174^{\circ}}$ Silver

Anonymous gift 1949-131-A, B or commissions for the aristocracy. Patticularly in London, such patronage and favor were eagerly sought, for they assured one's reputation as well as one's income. A typical example of the progress of a silversmith into the ranks of the leaders of taste and fashion is seen in the career of Thomas Heming. In addition to the cake basket already discussed (Figures $8 \mathrm{a}, \mathrm{b}$ ), the Museum collection contains a monumental and unusual tea urn by this prolific artist (Figures $13 a, b$ ). The son of a Shropshire tradesman, Thomas Heming was apprenticed in 1738 to become a silversmith, leatning his craft from a brilliant French 

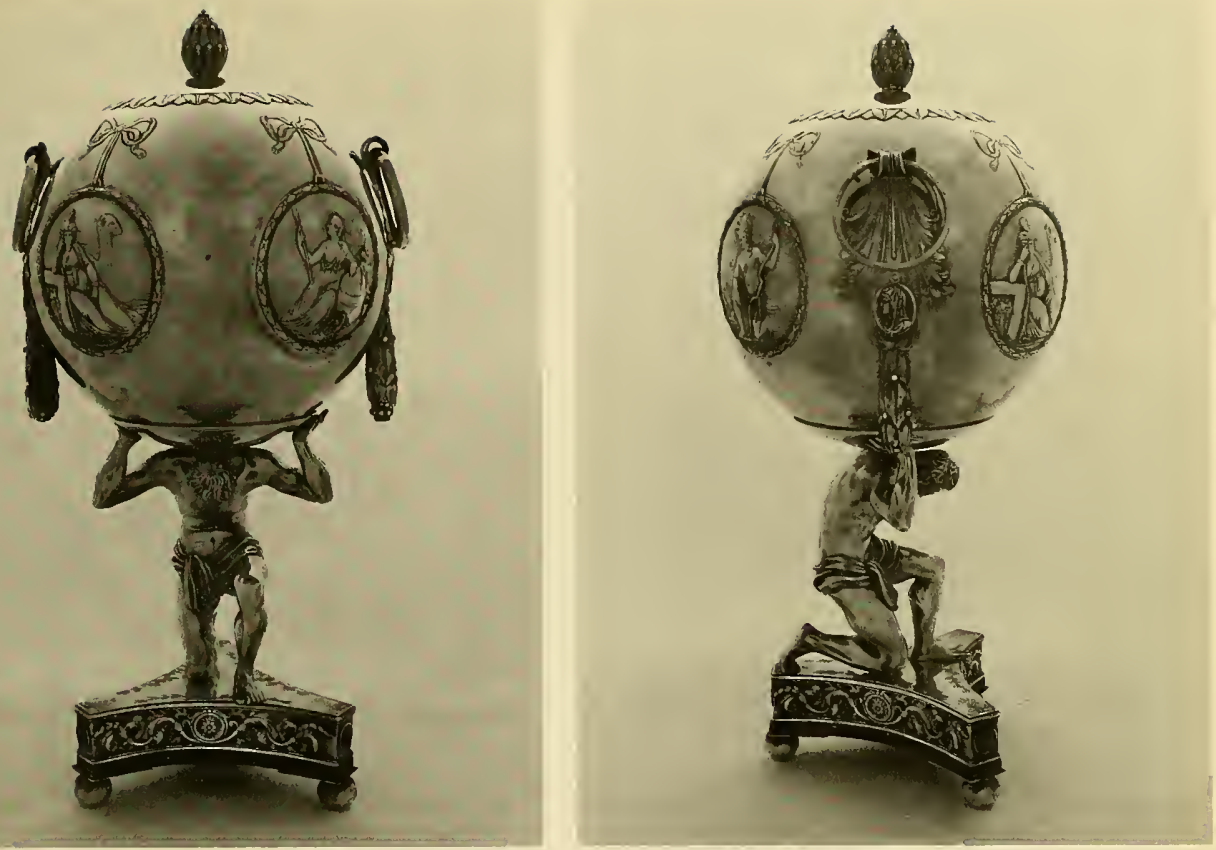

13a,b. Thomas Heming (active from 1745 , died between 1795-1801)

London, England

Tea urn, $1777-1778$

Silver

Gift of the Trustees of the Estate of James Hazen Hyde 1960-1-23
Huguenot silversmith, Peter Archambo. Heming's abilities and talents attracted royal attention, and in 1760 he was appointed Principal Goldsmith to King George III. In 1782 a scandal regarding the bills submitted for his work led to his replacement in this distinguished position, but during his active years Heming produced some of the finest works in silver among his London contemporaries.

The design of the tea urn in the Museum collection transforms a functional object into a bold sculptural statement. A finely modelled figure of Atlas supports the urn .
On his shoulders is the receptacle for water in the form of a globe. Depicted in four roundels on the globe are allegories of the four continents, carrying on an iconographic tradition already noted in the 17 th century (Figures $1 \mathrm{a}-\mathrm{f}$ ). The urn is fitted with a heating plug that can be inserted under the globe. The most ingenious aspect of the design, however, is in the clever disguising of the spigot from which the hot water issues. With the aid of a key that may be inserted beneath a hinged medallion at the side, the tap can be turned to cause water to flow from the hollow right hand pendant garland. Such clever manipulation 


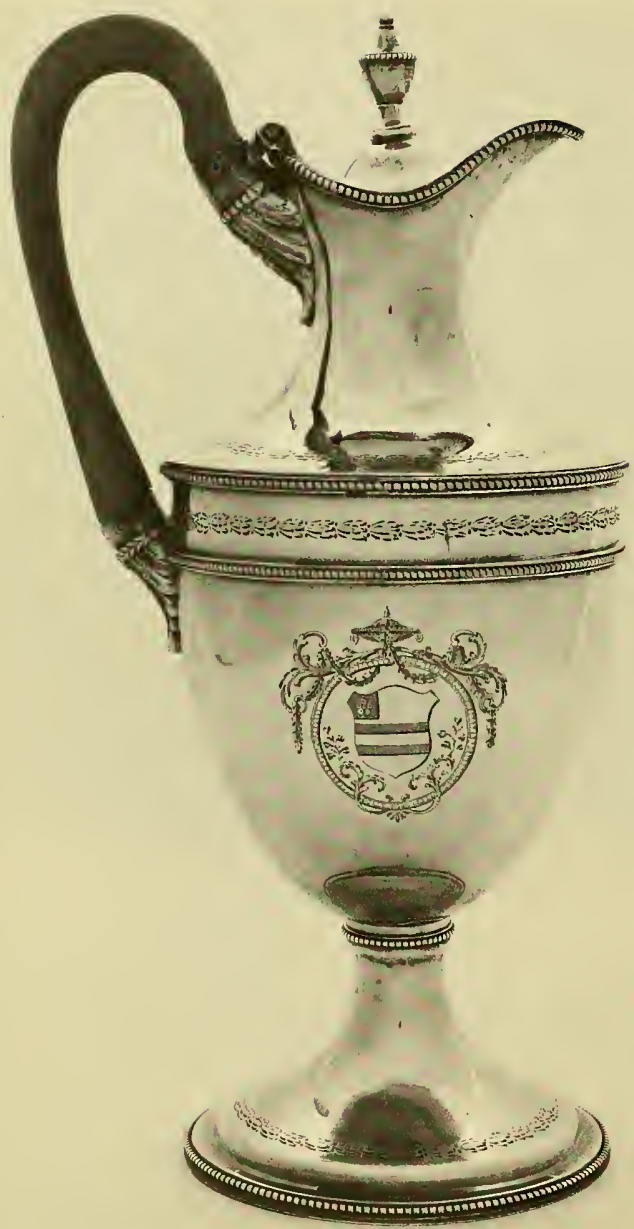

14. Maker unknown

London, England

Hot water jug, 1781-1782

Silver, wood

Bequest of Mrs. John Innes Kane 1926-37-125

15. Jean-Baptiste-Claude Odiot (1763-1850) Paris, France

Teapot, 1818-1819

Silver-gilt

Gift of James Hazen Hyde 1946-76-1

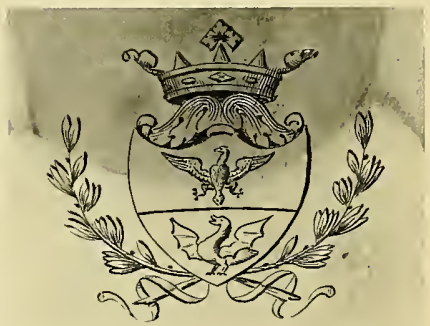

isb. Borghese coar of arms on Odiot teapor 


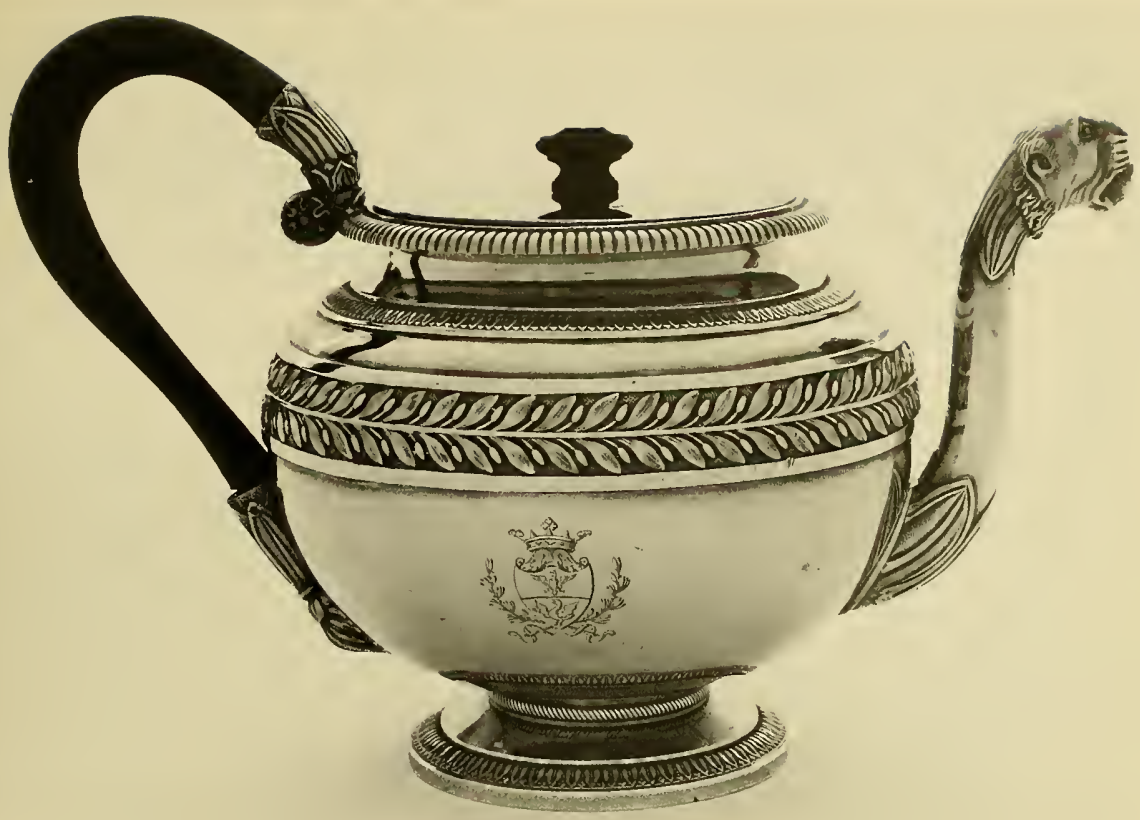

of functional forms, frequently encountered in 18 th-century decorative arts, is one of the most delightful aspects of design in the period.

By the later decades of the 18 th century, the seeming frivolity of the rococo had been supplanted by a revival of forms derived from the classical world, and silversmiths emulated the shapes of ceramics in domestic items such as coffee pots, tureens, and hot water jugs (Figure 14). The purity of form and minimal decoration used on holloware items such as this jug permitted craftsmen to produce objects within a shorter period of time, thus reducing labor costs while maintaining the sales price. By the late 18 th century, silversmiths could also obtain rolled sheet silver that could be cut and soldered into hollow cylinders or cones, obviating the hours necessary to hammer a form or "raise" it from a solid piece of thick silver. The econom ic just ification for speedier production was also based on a rapidly expanding market for the purchase of silver, and from the growing competition that silversmiths felt from the flourishing Sheffield plate industry that could provide silver-clad copper in the current taste at greatly reduced prices.
Not all silversmiths atound the turn of the igth century treated neo-classical styles as a simple reduction in effort, and superb examples of the classical taste emanated from workshops in London and Paris. One of the leading concerns that worked in the late neo-classical or Empire taste was the Parisian firm of Odiot (Figures 15-16). The Museum collection includes a bold silver teapot and cream jug from the Odiot workshops. The pieces bear the engraved arms of the Borghese family (Figure ${ }_{15} \mathrm{~b}$ ). JeanBaptiste-Claude Odiot was the head of the firm at the time when these pieces were made. The firm was a large one, and 


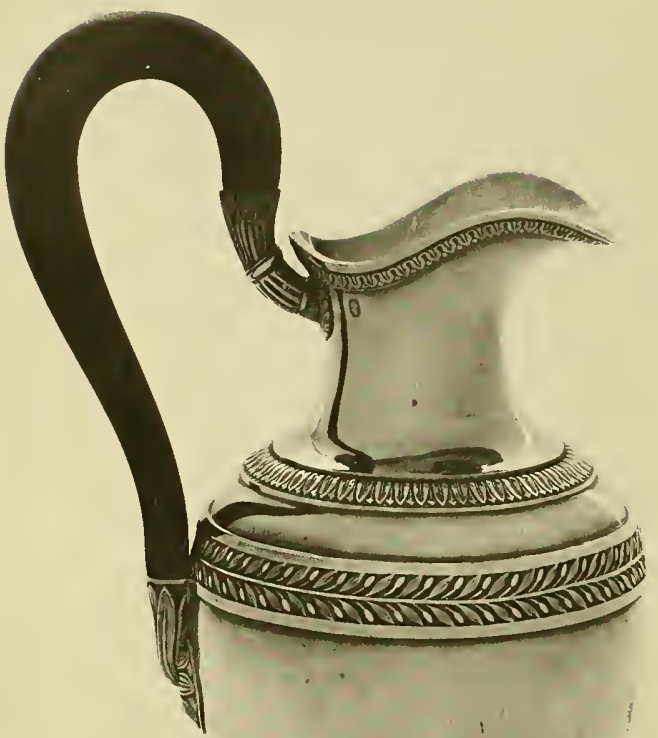

!

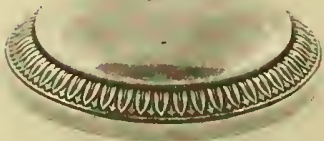

16. Jean-Baptiste-Claude Odiot $\left(1763^{-18} 50\right)$ Paris, France

Cream jug. 1818-1819

Silver-gilt

Gift of James Hazen Hyde 1946-76-2

17. Charles Odion Paris, France

Centerpiece, about $184^{\circ}$ Silver

Gift of the Trustees of the Estate of James Hazen Hyde 1960-1-22

numerous craftsmen were employed in different aspects of the production.

The Odiot firm received commissions for numerous important works, including silver for Napoleon and later, for Louis XVIII. Nineteenth-century production at the Odiot workshop, particularly toward the middle of the century, extended the range of display pieces to incredible proportions. A table centerpiece and compote bearing the arms of Solomon Rothschild (Figure ${ }^{7}$ ) is a tour-de-force statement in the use of precious materials, but with a somewhat less than successful montage of derivative form and decoration. 


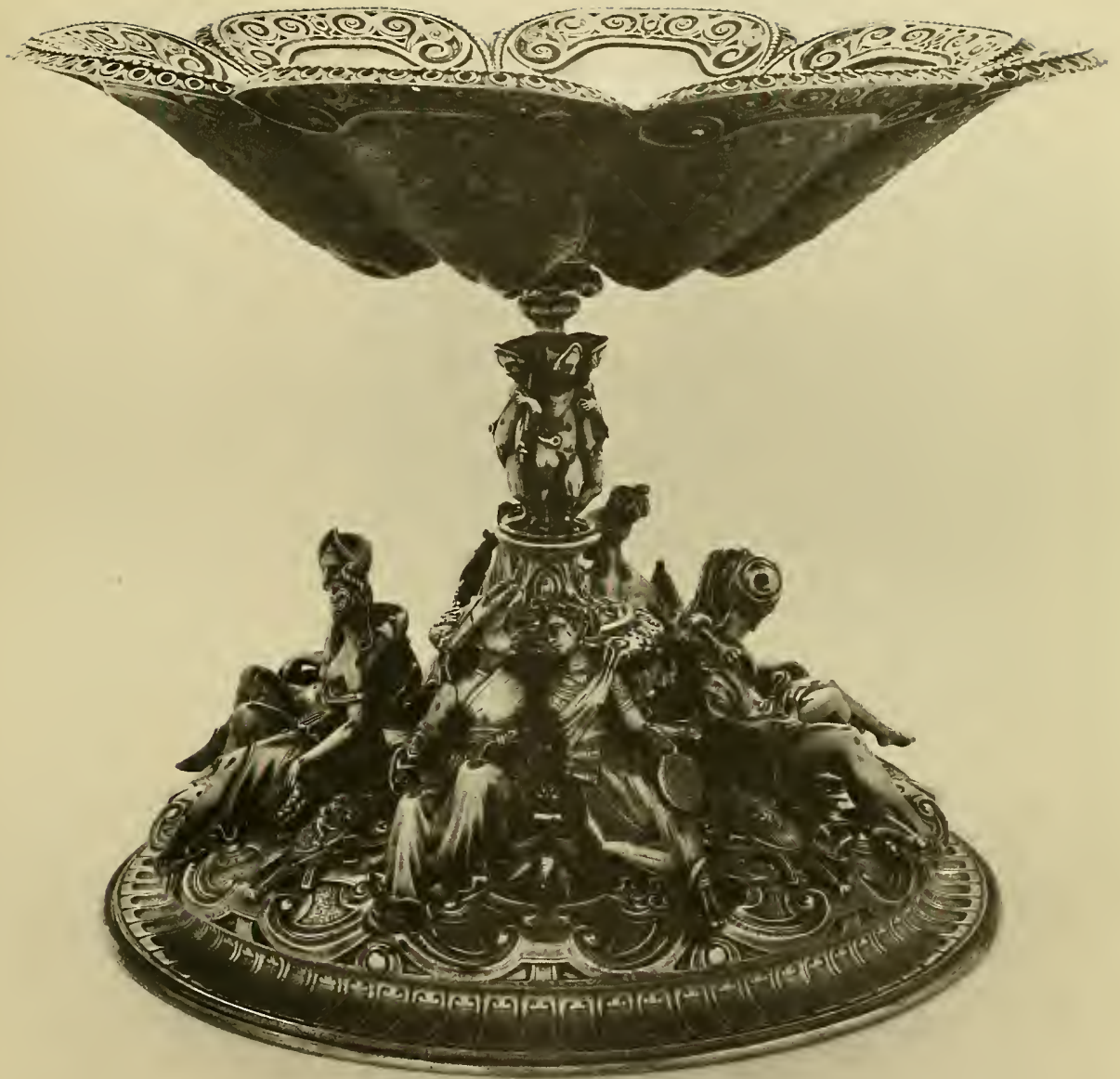




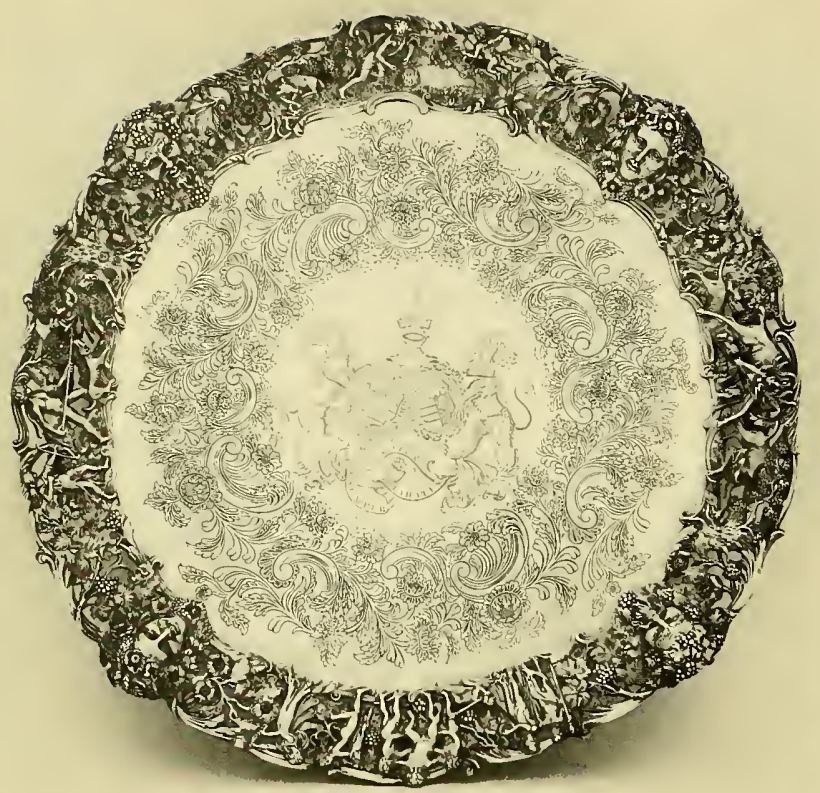

By the early 19th century, silver in the classical taste has developed from a delicate 18 th-century reticence of form and decoration into a style of massive propottions and pompous bearing. A large tray, weighing 220 ounces and measuring over two feet in diameter (Figure r8), combines classical references with a return of the Rococo. The elaborate cast and applied border of the tray is composed of figures, masks, animals, and flowers, but in the center is chased foliate scrollwork derived from rococo patterns. Nineteenth-century silver of unusual weight and proportion was frequently commissioned or purchased for commemorative purposes. This tray has a particularly interesting history, inscribed on the underside for posterity:

This salver was bought March 1824 by Major Genl. Fuller with a portion of the prize money awarded to his late lamented brother $\mathrm{Col}$. Wm. Fuller of the ist Dragn. Gds. in commemorarion of his having fallen Gloriously at the head of his Regiment whilst leading it on to Victory at the Memorable Battle of Waterloo on the 18 th of June 1815 .

Revivals of past styles continued through the igth century and included silver in the fashionable Gothic, Rococo, Renaissance, and Middle Eastern tastes. A plethora of styles could be seen in the workshops of
18. Maker's mark: EB

London, England

Tray, $1823-1824$

Silver

Gift of Mrs. J. Insley Blair $1950-37^{-1}$ silversmiths in Europe and America; by 1851, when the Great Exhibition was held in England, the styles were so numerous that one attempt to classify them included nine major sources of influence on European art and decoration-Egyptian, Greek and Roman; Byzantine, Saracenic, and Gothic; and Renaissance, Cinquecento, and Louis Quatorze. Among the great number of silversmiths who exhibited in 1851 was Joseph Angell, the scion of a London family of silversmiths. One work that Angell displayed and which received approbation from viewers was the "Vintage" jug, of which the Cooper-Hewitt has an 
19. Joseph Angell III

(about 1816-about 1891)

London, England

"Vintage" jug, 1854-1855

Silver-gilt

Gift of Miss Louise B. Scott 1936-21-1

I 854 -1 855 version (Figute 19).

The facetted body of the jug and the applied "cage" of architectural elements, grapevines, and laboring putti, lend the object a Gothic flavor, in spite of the fact that few individual motifs are related in any way to medieval silver design.

American silver in the igth century played out a similar fugue of competing styles. The Rococo revival found many champions in prolific centers of silver manufacturing such as Providence, Rhode Island, Baltimore, New York, Boston, and New Orleans, to mention only a few. The firm of

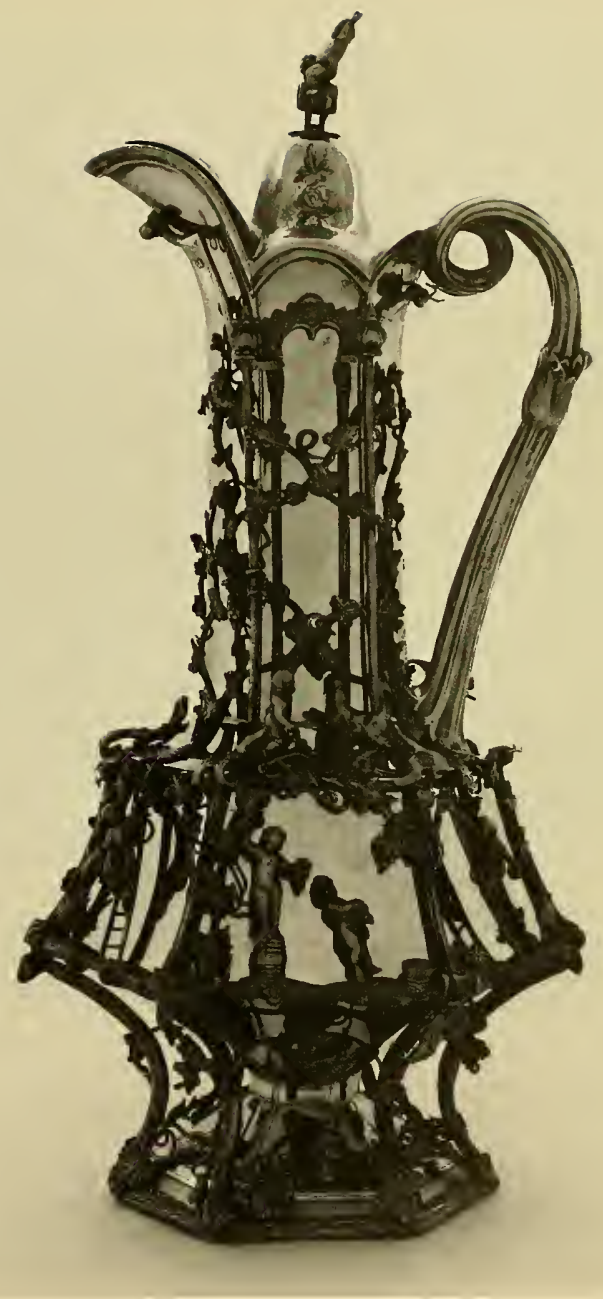




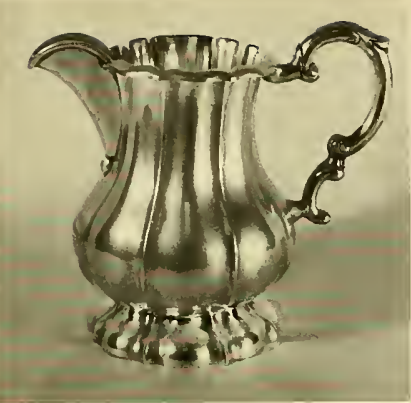

20. Hyde and Goodrich

New Orleans, Louisiana

Cream jug, about 1855

Silver

Gift of Mr. Harvey Smith

1968-90-2

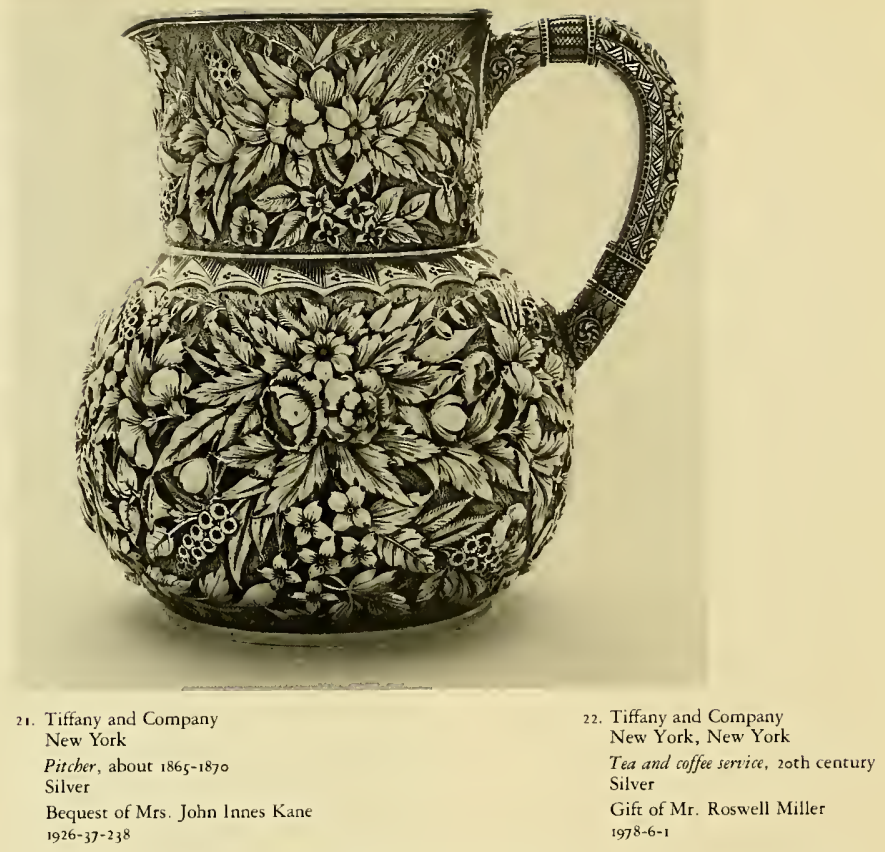

major corporate entites in the retail silver trade. Among the American firms whose work is represented in the Museum collection, three in particular deserve attention since the development of their style and techniques are indicative of a majority of silver manufacturers.

Tiffany and Company, Inc. of New York was founded in 1837 with the partnership of Charles L. Tiffany and John B. Young. Although silver was retailed by Tiffany and Young, it was under the direction of Edward C. Moore, who joined the firm later, that Tiffany and Company achieved a truly distinctive and internationally recognized style. In 1852 Tiffany and Company formally adopted the English sterling alloy, and their silver was marked to indicate this standard. In the Cooper-Hewitt collection is a water pitcher dated to the $1865^{-1870}$ period of the firm (Figures 21a-c). The entire body of the pitcher is covered with floral motifs against a stippled ground. The individual motifs are embossed from the interior to create raised areas on the surface; each swelling has been reworked from the surface with hammer and punches to create fine details and textures. This two-step process, 


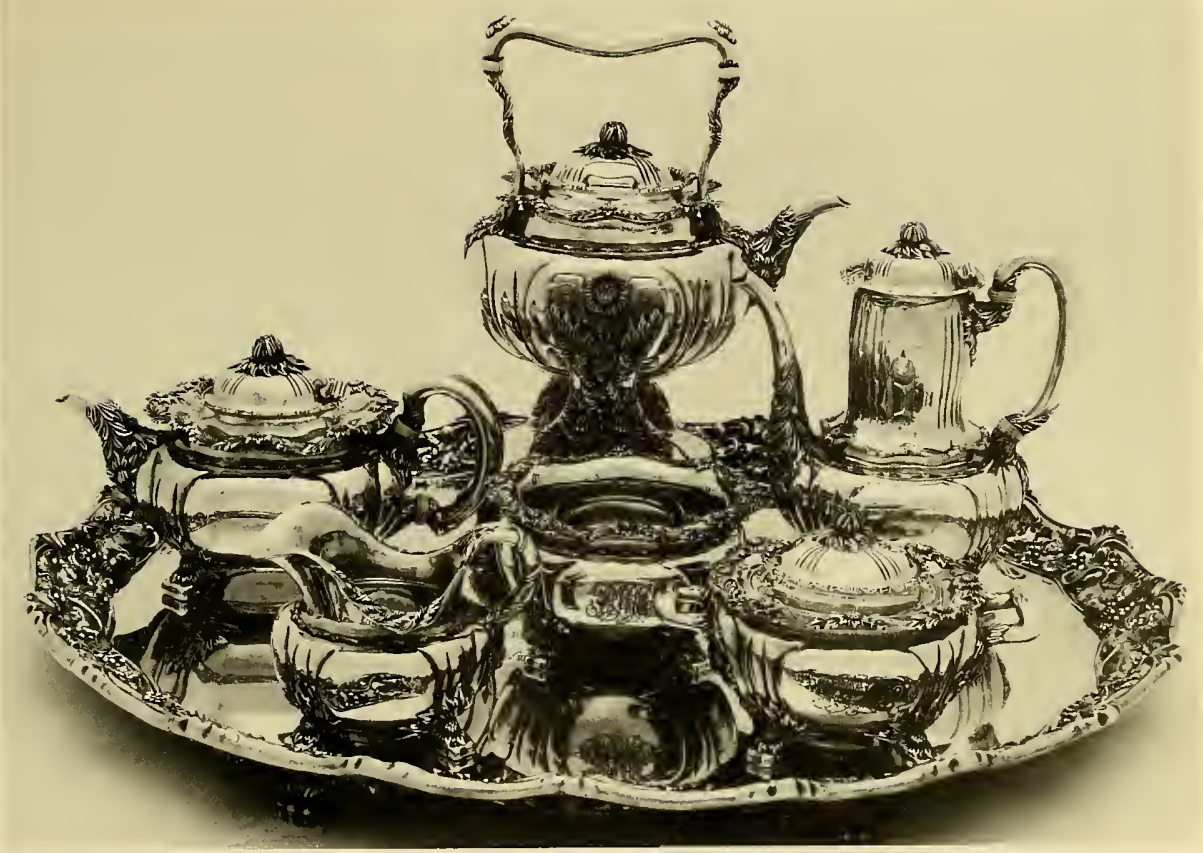

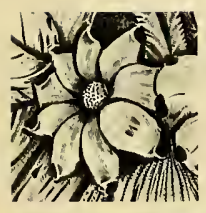

$2 \mathrm{rb}, \mathrm{c}$.

Details of Tiffany pitcher showing repoussé decoration on exterior and interior

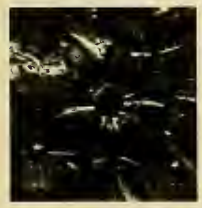

known as repoussé (literally, "re-pushed"), creates a negative mirror image of the pattern on the interior of the object (Figure $2 \mathrm{rb}, 2 \mathrm{rc}$ ). In addition to elegant domestic wates and specially commissioned services for distinguished clients, a large portion of Tiffany and Company's output was used for commemorative and presentation purposes. A seven-piece tea service (Figure 22) in the extremely popular "Chrysanthemum" pattern illustrates the monumentality of scale and weight common to many Tiffany services.

Like New York, Philadelphia supported an impressive number of silver manufactories from the early igth century onward. The Bailey, Banks \& Biddle Company was started in 1832 as a partnership between Joseph Trowbridge Bailey and Andrew Kitchen. Their workshop and retail outlet was located on Chestnut Street in the city. Following the death of Kitchen, the firm remained within the Bailey family, although subsidiary partnerships were formed. In 1878 , the firm became Bailey, Banks \& Biddle. The company produced domestic wares in a multitude of styles; among the most charming, however, is the Japanese-inspired patretn in repoussé work 


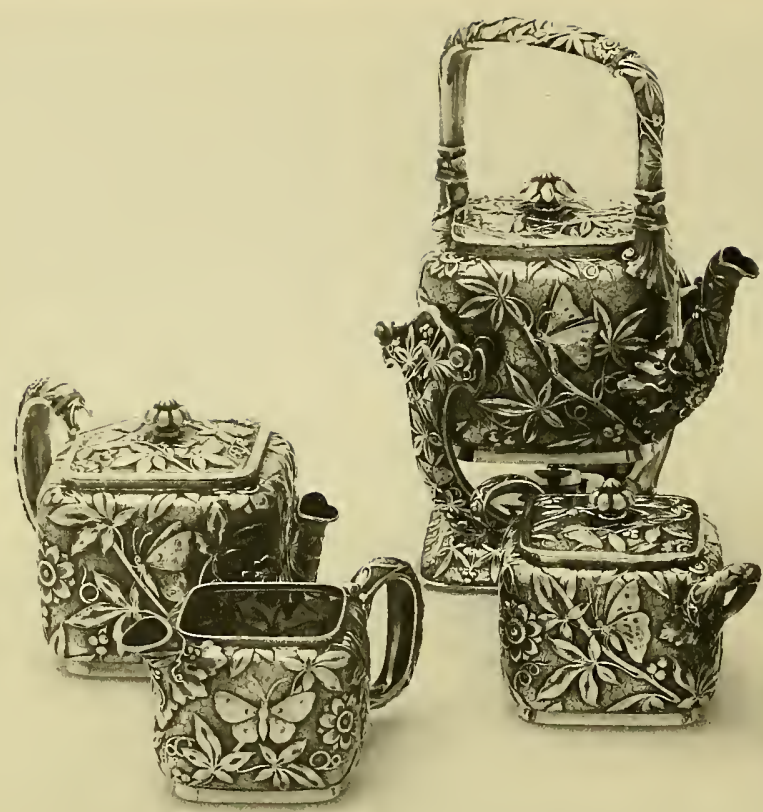

23. Bailey, Banks \& Biddle Company Philadelphia Pennsylvania

Tea and coffee service, about 1888 Silver

Gift of Mrs. Norris W. Harkness 1980-20-1-6

seen on a tea service in the Museum collection, dated to the late 1880 s (Figure 23). Vines, butterflies, and flowers enrich each piece, and the entire service is self-consciously Orientalized by the design of all pieces in the shape of squares. Handles and spouts are set at the corners lending a sense of geometric order to the lush ensemble.

A third great force in the history of 19thcentury American silver was the Providence, Rhode Island firm of Gorham. Jabez Gorham, the founder of the vast and highly successful company, was born in Providence in 1792 , and learned the art of sil- 


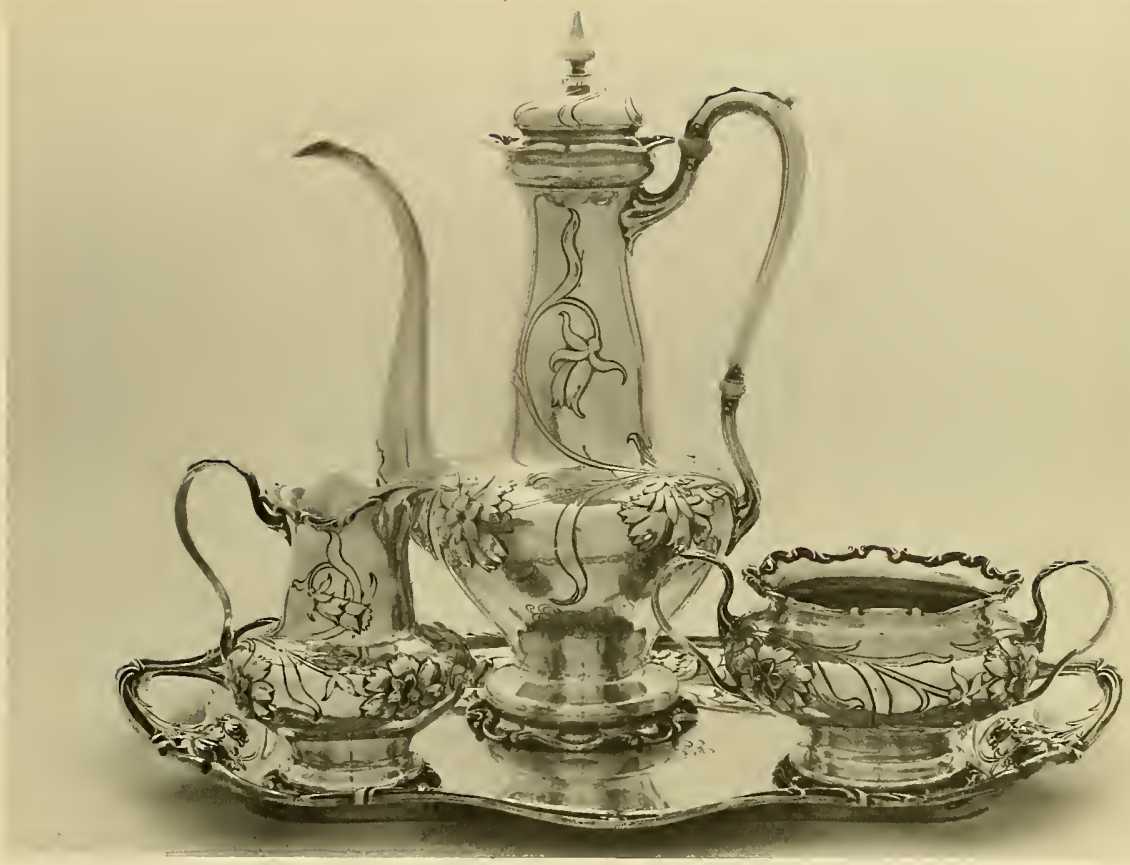

24. Gorham Company

Providence, Rhode Island

Coffee service, 1903

Silver

Gift of Mrs. Edward C. Moen $1963-77-1$ versmirhing as an apprentice to Nehemiah Dodge. Before 1820, Gorham was in control of his own workshop, in which he manufactured a substantial quantity of jewelry. The concern went through a series of name changes throughout the igth century. In the early 20 th century the firm began to acquire other smaller silver manufactories, including the Mt. Vernon Company Silversmiths, Inc, and the Alvin Silver Company. A coffee service from the early zoth century in the Cooper-Hewitt collection (Figure 24 ) is ornamented in the American version of the art nouveau style. The English art nouveau designer William
Christmas Codman worked at the factory in the late igth century and helped to popularize the hammer-texture surface appearance on manufactured goods sold by Gorham under the name "Martele." The Museum coffee service is smooth finished, each piece enveloped by swirling floral motifs. A sinuous profile and handle and an exaggerated Middle Eastern neck and spout on the coffee pot suggest a conservative approach to art nouveau exoticism typical of many 19th-century American pieces. 


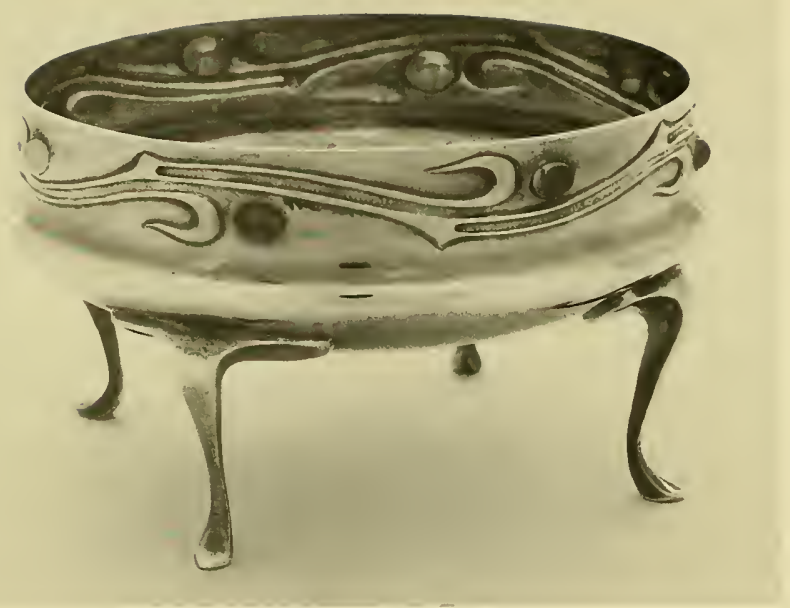

Of all the firms that produced art nouveau silver in England, few achieved the general popular acceptance of Liberty and Company (Figure 25). Established in 1875 on Regent Street, Liberty's labelled themselves "jewellers, goldsmiths and silversmiths, dealers in gold, silver and precious stones, curios and articles of vertu." Work of noted designers was sold by Liberty and Company, including the masterful designs of C. R. Ashbee, founder of the Guild of Handicrafts. Liberty's "Cymric" line, of which this small footed dish is an example, blended archaic Welsh motifs with the sinuous line of art nouveau. This dish, made in
Bitmingham by the firm of Haseler who supplied a considerable quantity of silver to Liberty's, also incorporates cabochon opals into the graceful design of the object.

In spite of the nearly universal popularity of art nouveau (known in Italy as "stile Liberty"), other revivalist trends that had surfaced in the 19 th century continued to be nourished by prolific and eccentric designers. A unique survival of the $18905 \mathrm{de}-$ cade is an unusual ltalian coffee service in a florid neo-Renaissance style (Figure 26). The service, which inicorporates 16 thcentury grotesques, rinceaux, and putti
25. Liberty and Company

London, England

Footed dish, 1902-03, made by

Haseler of Birmingham

Silver, opals

Anonymous gift

$1952-166-108$ into the complex surface pattern, was made by a relatively unknown silversmith named Agostino Coppini. The tray of the service is inscribed on the underside, indicating that the service received a silver medal award at the 1898 Turin Exposition.

Silver in the 2oth century has reflected many of the concerns of designers in all aspects of the decorative arts, not the least important of which was the resolution of the relationship between the individual silversmith and the machinery of mass production. Although the separation of art and industry into two adjunct endeavors 


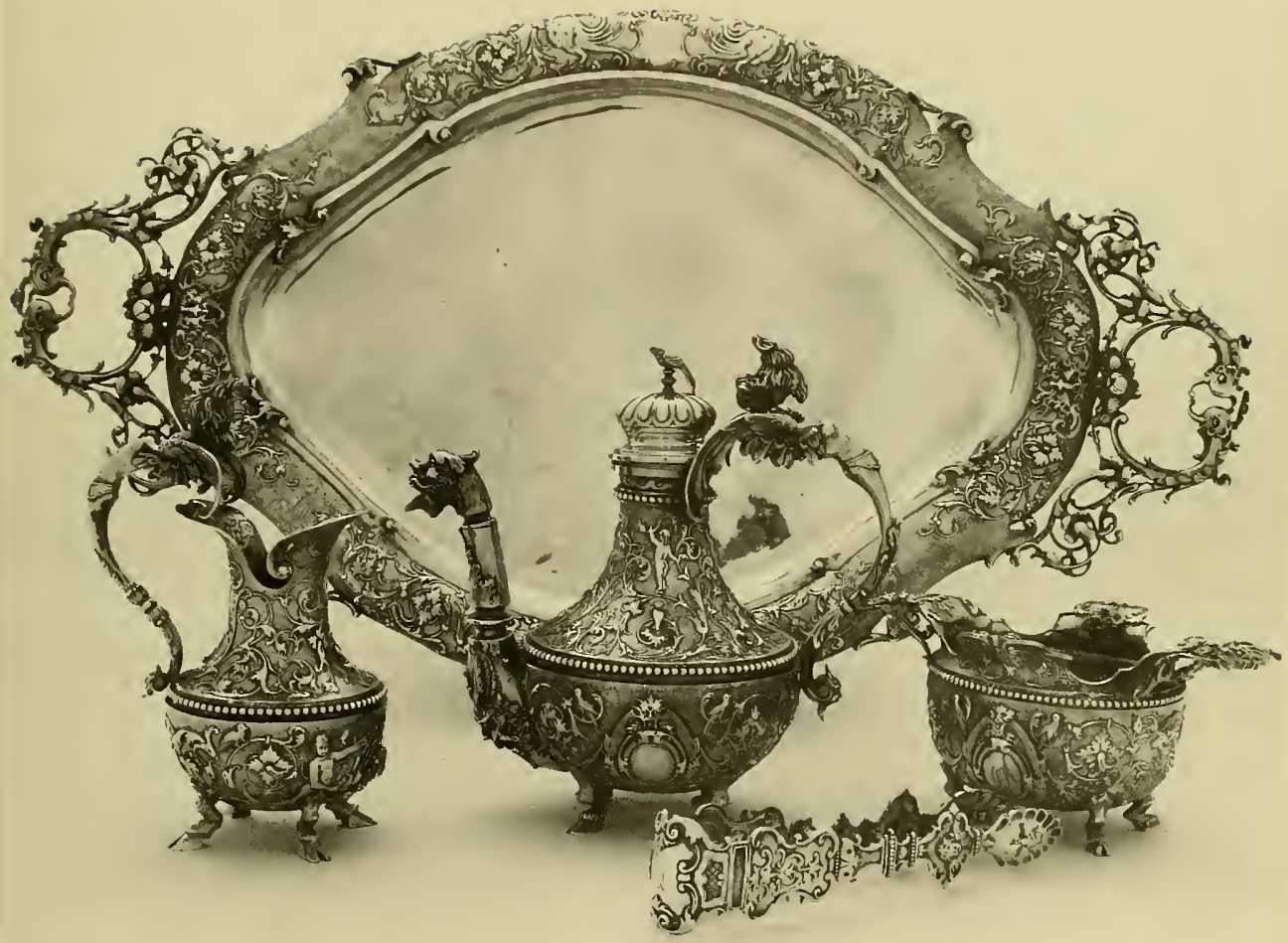

26. Agostino Coppini

Italy

Coffee service, about 1898

Silver

Gift of Mrs. J.A.Q. Franks

1977-62-1-5 


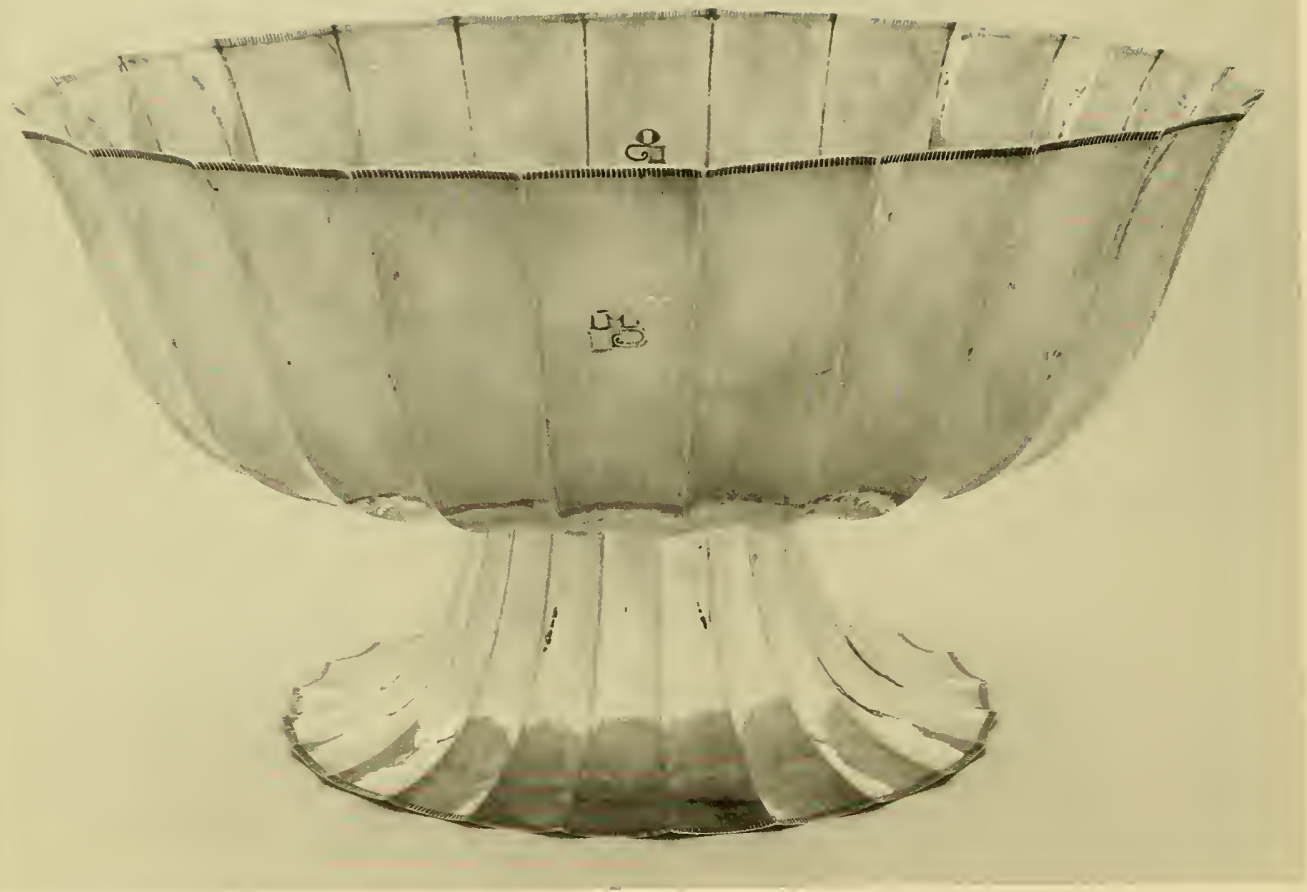

27. Josef Hoffmann (1870-1956) Vienna, Austria

Bowl, 1917

Silver

Gift of Ely Jacques Kahn 1962-227-1 
28. Dagobert Peche (1887-1923)

Vienna, Austria

Vase, about 1920

Silver

Gift of Ely Jacques Kahn

1962-227-2

can be traced back through the igth century, many designers in the present century have been acutely sensitive to the problems of design as it affects the objects of daily life in a rapidly changing and highly industrialized world. The Cooper-Hewitt collection contains objects in silver from the early decades of the century, including two superb pieces of silver by artists associated with the Wiener Werkstaette-Josef Hoffman (Figure 27) and Dagobert Peche (Figure 28). Many designers for decotative arts during this period were disenchanted with the profusion of seemingly senseless ornament typical of art nouveau design and were equally vocal in their objections to the profusion of revival styles that made up the history of the 19th century. Joseph

Hoffman, along with Koloman Moser, directed the activities of the Wiener Werkstaette. Hoffman's aesthetic sensibility revealed itself in the design of objects intended for functional use, but with little or no unnecessary ornamenation; the silver bowl in the Museum collection, dated 1918 , is less severe than many of Hoffman's other designs for silver. The lyrical quality in this work by Hoffman is matched in the vase by a later arrival at the Wiener WerkstaetteDagobert Peche. Peche's design incorporates floral motifs in the design, consisting

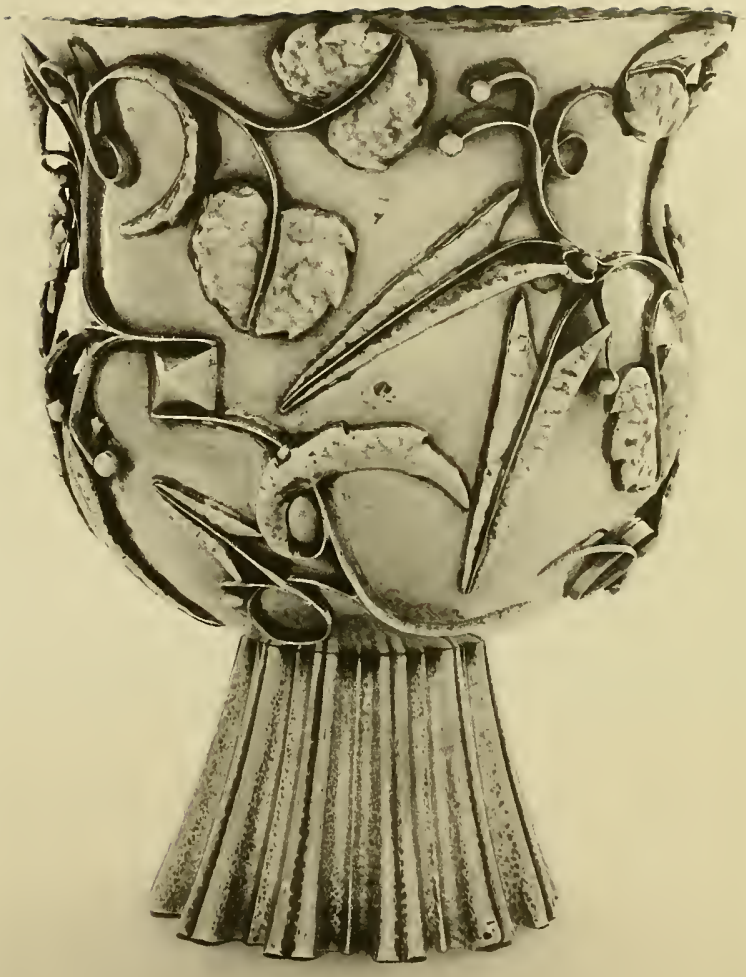




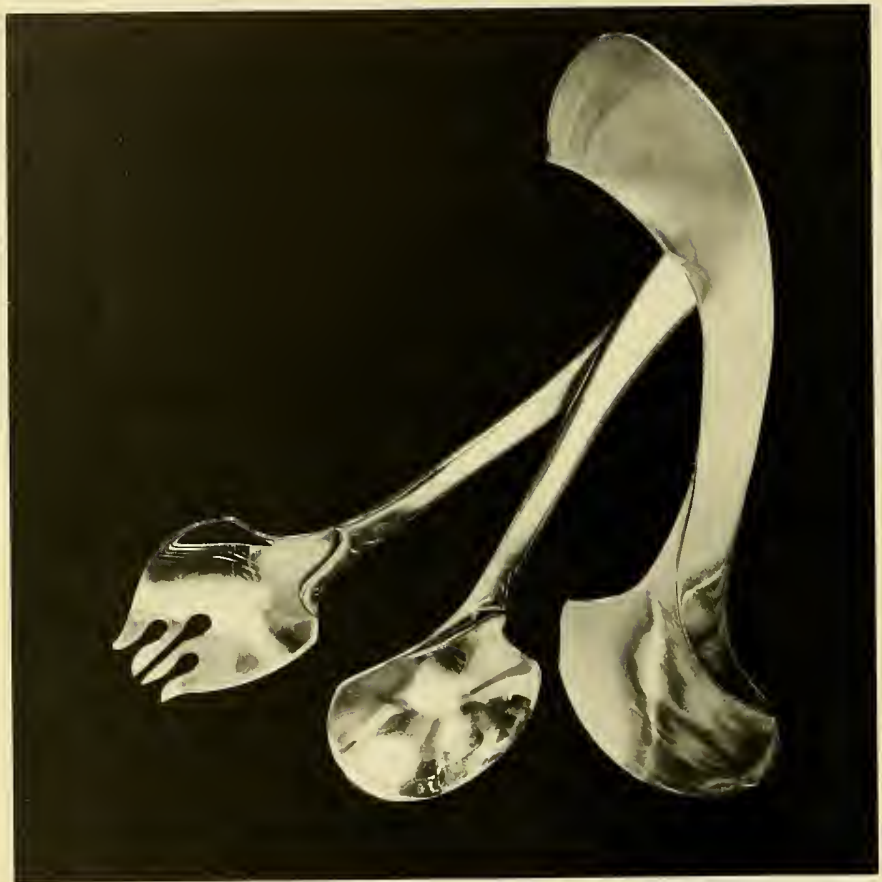

29. Anna Krohn Graham United States

Travelling flatware, 1978 Silver

Gift of Aaron Faber Gallery 1979-60-3

of twining foliage.

The Museum's nascent collection of contemporary silver includes pieces of jewelry, holloware, and flatware by contemporary American and European designers. Among the more recent acquisitions is a travelling flatware service by Anna Krohn Graham (Figure 29). The knife, fork, and spoon are designed to fit into one another in a series of interlocking curves. The overall design of the set unites both form and function in a sculptural statement that emphasizes the inherent qualities of silver - reflectiveness, purity of color, and ability to be readily manipulated in complex constructions.
Silver has managed to survive the harsh reality of economic necessity because it has been cherished and preserved by individuals and museums. This ancient and respected craft, which has made its influence felt throughout nearly every historic period, is preserved for future generations in the collections of the Cooper-Hewitt Museum, the Smithsonian Institution's National Museum of Design.

David Revere McFadden

Curator of Decorative Arts 


\section{Selected Bibliography of Introductory Books on Silver}

Avery, C. Louise. Early American Silver. New York: Russell and Russell, 3969.

Banister, Judith. An Introduction to Old English Silver. London: Evans Bros., 1965.

-. English Silver. London: Hamlyn, 1969.

Buhler, Kathryn C. American Silver. Cleveland: World Publ. Co., $195^{\circ}$.

Bulgati, C.G. Argentieri gemmari e orafi d'Italia. Rome: Lorenzo del Tutco, 1958.

Came, Richard. Silver. New York: G.P. Putnam's Sons, 1961.

Carpenter, Charles H. Tiffany Silver. New York: Dodd, Mead, 1978.

Clayton, M. The Collector's Dictionary of the Silver and Gold of Great Britain and North America. New York and Cleveland: The World Publishing Co., 197 .

Culme, J. and Strang, J.G. Antique Silver and Silver Collecting. London, New York, Sydney, Toronto: Hamlyn, 1973.

-. Nineteenth Century Silver. London: Country Life Books, 1977.

Davis, Frank. French Silver. New York: Praeger, 1970.

Delieb, Eric. Silver Boxes. London: H. Jenkins, 1968.

Dennis, Faith. Three Centuries of French Domestic Silver; its makers and its marks. New York: Metropolitan Museum of Art, 1960.

Fales, Martha Gandy. Early American Silver for the Cautious Collector. New York: Funk and Wagnalls, 1970.

Finlay, Ian. Scottish Gold and Silver Work. London: Chatto \& Windus, 1956.

Frederiks, J.W. Dutch Silver from the Renaissance until the end of the eighteenth century, 4 vols. The Hague: M. Nijhoff, 1952-1961.

Grimwade, Arthur G. London Goldsmiths 1697-1837. London: Faber and Faber, 1976.

Hayward, John F. Huguenot Silver in England, 1688-1727. London: Faber and Faber, 1959.

Holland, Margaret. Old Country Silver: an account of English provincial Silver, New York: Newton Abbott, David \& Charles, 197 I.

Honour, Hugh. Goldsmitbs and Silversmiths. New York: G.P. Putnam's Sons, $197^{1 .}$

Hood, Graham. American Silver: A History of Style, 1650-1900. New York, Washington, D.C.: Praeger, 1971.

Hughes, Graham. Modern Silver tbroughout the World 1880-1967. New York: Crown, 1967.

Jackson, Charles James. An Illustrated History of English Plate... London: Country Life, 1911, reprinted, 3967.

Lever, Christopher. Goldsmiths and Silversmiths of England. London: Hutchinson \& Co., 1975.

Link, Eva M. The Book of Silver. New York: Praeger Publishers, 1973.

McClinton, Katherine Morrison. Collecting American 19tb-Century Silver. New Yotk: Charles Scribner's Sons, 1968.

McNab, Jessie. Silver (The Smitbsonian Illustrated Library of Antiques). New York: Cooper-Hewitt Museum, 1981.

Oman, Charles. English Domestic Silver. London: A \& C Black Ltd., 1965.

Rainwater, Dotothy T. American Silver Manufacturers. Hanover, Pa.: Everybody's Ptess, 1966.

Rowe, Robert. Adam Silver, London: Fabet and Faber, 1965.

Taylor, G. Silver. Baltimorẹ: Penguin Books, 1964.

Wardle, Patricia. Victorian Silver and Silver Plate. New York: Universe Books, 1970. 
<smiles></smiles> 


\section{Cooper-Hewitt Museum}

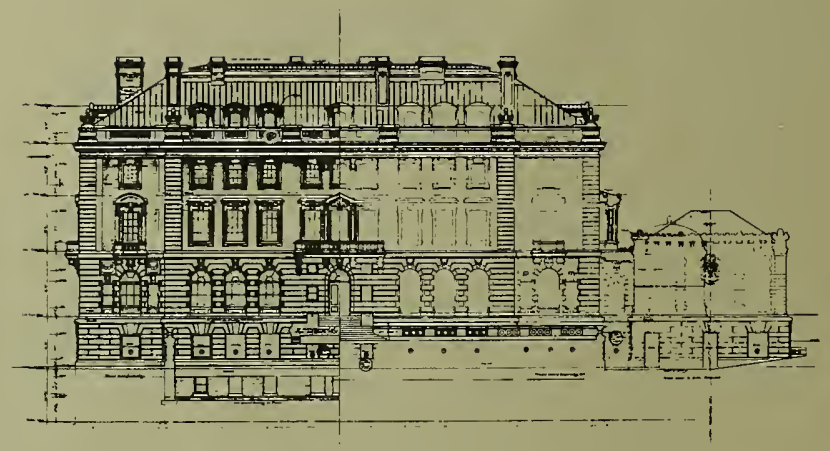

2 East 9ist Street

New York NY 10028 





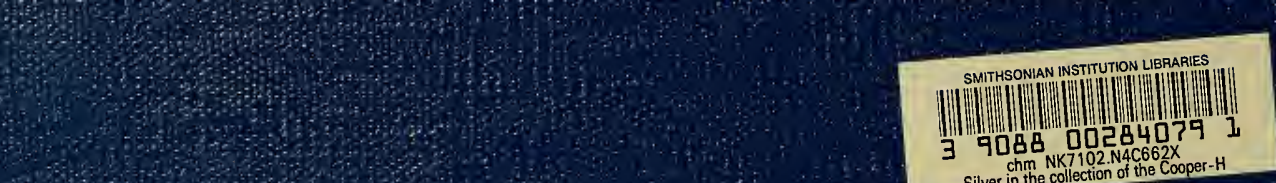

chm NK7102. N4C662X
Silver in the collection of the Cooper-H 